\title{
Análise Quimiométrica da Distribuição de Quimioterápicos Antimicrobianos (Fluoroquinolonas e Sulfonamidas) na Baía de Ubatuba
}

Dissertação apresentada ao Instituto de Química de São Carlos da Universidade de São Paulo como parte dos requisitos para a obtenção do título de Mestre em Química Analítica.

Área de concentração: Química Analítica e Inorgânica

Orientador: Prof. Dr. Eduardo Bessa Azevedo

São Carlos/SP

2016 


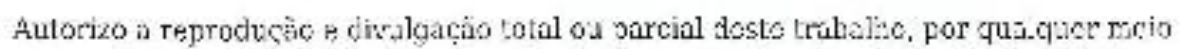

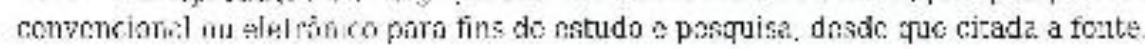

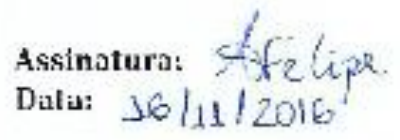

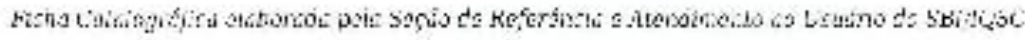

Da Silwa, Lus Felipe

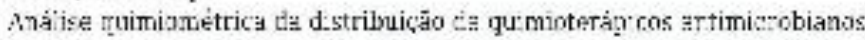

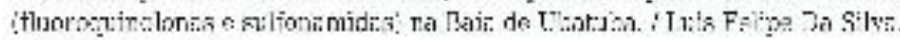
- Sácir.: 2016

431

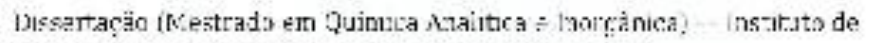

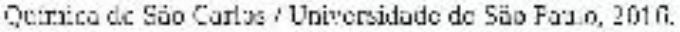

Tdiçán mo:isarili:

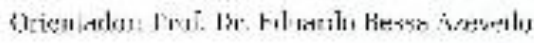

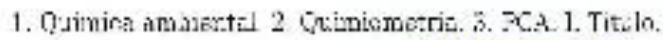

Referincicts Biblogrifisas

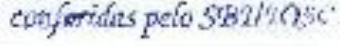




\section{DEDICATÓRIA}

Dedico este trabalho aos meus pais, que sempre estiveram presente em todos os momentos da minha vida me apoiando e ensinado o caminho certo. Graças a eles que estou concluindo mais esta etapa.

À minha noiva, Jéssica, pelo carinho, compreensão e amor. Por apoiar e participar de todas as minhas decisões.

Aos meus irmãos Luis Otávio e Luis Fabiano, aos familiares e amigos que me proporcionaram momentos de alegrias, conselhos que jamais esquecerei e pelo apoio na jornada.

Dedico também ao povo brasileiro, ao qual tenho a dívida moral de contribuir para o crescimento do país com o estudo financiado pelo suor de cada um. 


\section{AGRADECIMENTOS}

Agradeço primeiramente a Deus pela oportunidade de realizar este trabalho; pelas inúmeras vezes em que nele depositei minha esperança e em nada me desamparou.

À minha família pelo incentivo e colaboração, em especial ao José Luiz da Silva e Idalina Bondância da Silva, meu pai e minha mãe, um guerreiro e sua fiel escudeira, aqueles que ensinaram todos os valores que tenho e que sonham todos os dias com um futuro melhor para seus filhos. Esta conquista também é de vocês.

Ao meu orientador Eduardo Bessa Azevedo, pela amizade e por estar sempre à disposição, com muitos ensinamentos e sempre ajudando muito durante a realização do trabalho. Aos professores Álvaro José dos Santos Neto, Fernando Mauro Lanças e Maria Olímpia de Oliveira Rezende por disponibilizarem seus laboratórios para análises e contribuírem com este trabalho.

Agradeço ao meu amigo Anderson Luigi Luiz por toda dedicação ao me auxiliar nas análises cromatográficas dos antimicrobianos; sua presteza, conhecimento e amizade foram de grande valia e serei sempre grato.

Aos meus amigos do Laboratório de Desenvolvimento de Tecnologias Ambientais - LDTAmb, Ana Luiza, Leticia, Vanessa, Rodrigo, Fellipe, Rafaely, Thiago, Maykel e Pedro, incluindo também a Shirlei, Vânia e a professora Teca pela amizade, pelas conversas, conselhos, alegrias e tristezas vivenciados juntos.

Por fim agradeço ao Conselho Nacional de Desenvolvimento Científico e Tecnológico - CNPQ, pelo fomento destinado à realização deste trabalho. 


\section{RESUMO}

Os quimioterápicos antimicrobianos são considerados contaminantes emergentes, com a capacidade de criar resistência em bactérias. Têm sido o foco de inúmeras pesquisas relacionadas a impactos ambientais, mas no Brasil, as pesquisas sobre a sua ocorrência em ambientes aquáticos continentais e costeiros são escassas. A cidade de Ubatuba tem uma densidade demográfica cinco vezes maior que a média nacional, aumentada em até doze vezes no verão, pressionando ainda mais os ecossistemas da região. Os rios Acaraú, Lagoa-Tavares, Grande e Indaiá deságuam na baía de Ubatuba, comprometendo a qualidade das suas águas. Este trabalho investigou a contribuição da descarga desses rios para a ocorrência e distribuição de quimioterápicos antimicrobianos (fluoroquinolonas e sulfonamidas) na baía de Ubatuba. Foi analisado um total de 36 amostras de água superficial. As coletas foram realizadas no período seco/chuvoso de 2014/2015. Para a determinação e quantificação dos fármacos foi utilizada SPE como método de preparo de amostra e CLAE-MS/MS para a detecção e quantificação dos antimicrobianos estudados. As características físico-químicas $\mathrm{pH}$, temperatura, salinidade, oxigênio dissolvido, potencial redox (ORP), além do Carbono Orgânico Dissolvido (COD) também foram determinados para caracterização das águas da região. A distribuição espaçotemporal dos fármacos e a possível associação com os demais dados investigados foi avaliada pela ferramenta quimiométrica CA, visando à extração da maior quantidade possível de informações. Os rios e, consequentemente a baía estavam impactados pelo despejo de esgoto doméstico e os seguintes quimioterápicos antimicrobianos foram encontrados: sulfametoxazol (SMX), sulfatiazol (STZ), sulfacloropiridiazina (SCP), sulfaquinoxalina (SQX) e norfloxacina (NOR). Observou-se uma variação espacial e temporal, nos perfis de contaminação revelados pela CA.

Palavras-Chave: Fluoroquinolona; Sulfonamida; Ubatuba; Cluster Análise. 


\begin{abstract}
Antimicrobial chemotherapeutical agents are considered emerging contaminants capable of creating bacterial resistance. They have been the focus of numerous studies related to environmental impacts, but in Brazil, there is little research on their occurrence in continental and coastal aquatic environments. The city of Ubatuba has a population density five times higher than the national average, which may be increased up to twelve times during the summer, pushing further the region's ecosystems. The rivers Acaraú, Lagoa-Tavares, Grande and Indaiá flow into Ubatuba Bay, compromising the quality of its waters. This work investigated those rivers' discharge contribution on the occurrence and distribution of antimicrobial chemotherapeutical agents (fluoroquinolones and sulfonamides) in Ubatuba Bay. Thirty-six samples of surface water were analyzed. The samples were withdrawn during the dry and rainy seasons of 2014 and 2015, respectively. For the determining and quantifying the antimicrobial chemotherapeutical agents, it was used SPE as a sample preparation method and HPLC-MS/MS for their detection and quantification. Physicochemical characteristics like $\mathrm{pH}$, temperature, salinity, dissolved oxygen, and redox potential (ORP), as well as dissolved organic carbon (DOC) were also determined to characterize the waters of the region. The spatial-temporal distribution of the agents and their possible association with other investigated data was assessed by the chemometric tool CA, aiming at extracting the greatest possible amount of information. The rivers and, consequently, the bay were contaminated by domestic sewage discharges and the following antimicrobial chemotherapeutical agents were detected: sulfamethoxazole (SMX), sulfathiazole (STZ), sulfachloropyridiazine (SCP), sulfaquinoxaline (SQX), and norfloxacin (NOR). The contamination profiles revealed by the CA showed a spatial variation and a temporal one.
\end{abstract}

Keywords: Fluoroquinolone; sulfonamide; Ubatuba; Cluster Analysis. 


\section{LISTA DE FIGURAS}

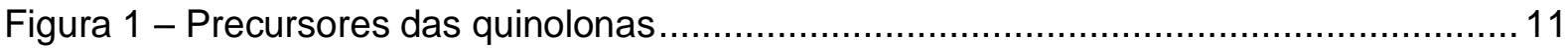

Figura 2 - Estrutura geral das fluoroquinolonas ......................................................... 12

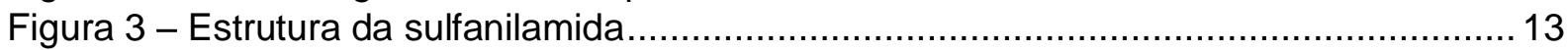

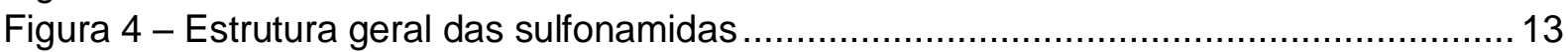

Figura 5 - Localização das aminas N1 e N4 nas sulfonamidas....................................... 14

Figura 6 - Etapas da Extração em Fase Sólida (SPE, do inglês Solid-Phase Extraction). ... 17

Figura 7 - Estrutura da Fase Oasis HLB ${ }^{\circledR}$ (Waters). .................................................... 18

Figura 8 - Imagem da Baía de Itaguá em Ubatuba e pontos de amostragem.....................24

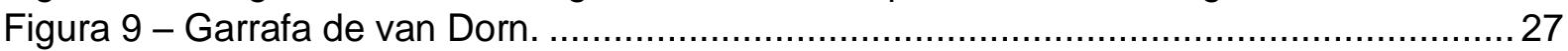

Figura 10 - Sonda paramétrica YSI Professional Plus..................................................... 27

Figura 11 - ( $\mathrm{pH}-7,5)$ em ambas as campanhas de amostragem ( $\square$ inverno e $\square$ verão).... 35

Figura 12 - ORP em ambas as campanhas de amostragem ( $\square$ inverno e $\square$ verão). ............ 36

Figura 13 - Salinidade em ambas as campanhas de amostragem ( $\square$ inverno e $\square$ verão). .. 39

Figura 14 - (OD - Cs) em ambas as campanhas de amostragem ( $\square$ inverno e $\square$ verão) ... 40

Figura 15 - Concentração de carbono orgânico em ambas as campanhas ......................... 42

Figura 16 - Exemplo de cromatograma de íons totais obtido para uma amostra da água do

mar sintética, fortificada com fluoroquinolonas e sulfonamidas $\left(500 \mathrm{ng} \mathrm{L}^{-1}\right) \ldots \ldots \ldots \ldots \ldots \ldots \ldots . . . . . . . . . . . .43$

Figura 17 - HCA da campanha inverno 2014 ........................................................ 48

Figura 18 - HCA da campanha verão 2015 ........................................................... 50

Figura 19 - HCA de ambas a campanhas ( ${ }^{*}$ são pontos de amostragem do verão de 2015). 


\section{LISTA DE TABELAS}

Tabela 1 - Georreferenciamento dos pontos de coleta: (I) Rio Indaiá, (G) Rio Grande, (L) Rio Lagoa-Tavares, (A) Rio Acaraú e (B) Baía de Itaguá em Ubatuba......................................25

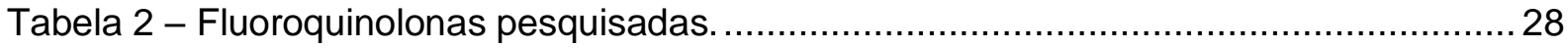

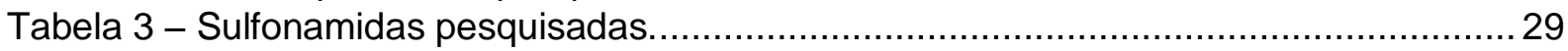

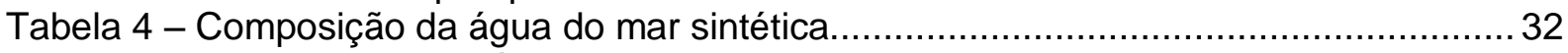

Tabela 5 - Resultado das análises realizadas in situ.................................................. 34

Tabela 6 - Classificação das águas segundo a Resolução CONAMA 357/05 .................... 37

Tabela 7 - Concentração de saturação de oxigênio dissolvido de cada ponto de

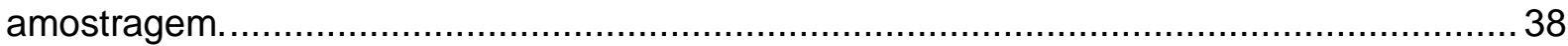

Tabela 8 - Concentração carbono orgânico dissolvido em cada ponto de amostragem. ..... 41

Tabela 9 - Gradiente de eluição utilizado no método cromatográfico multirresíduo desenvolvido (vazão $=0,300 \mathrm{~mL} \mathrm{~min}^{-1}$ ).

Tabela 10 - Parâmetros de quantificação e confirmação no modo MRM (Multiple Reaction Monitoring). Tempo de aquisição (dwell time) = 0,030 s. .............................................. 44

Tabela 11 - Linearidade para a detecção de sulfonamidas e fluoroquinolonas................... 45

Tabela 12 - LOD e LOQ do método utilizado................................................................. 46

Tabela 13 - Resultado da determinação de antimicrobianos SAs e FQs nos pontos de coleta

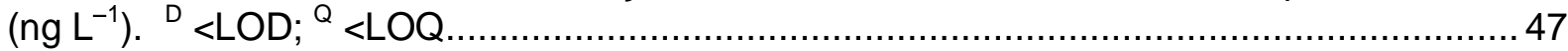




\section{SUMÁRIO}

1 INTRODUÇÃO

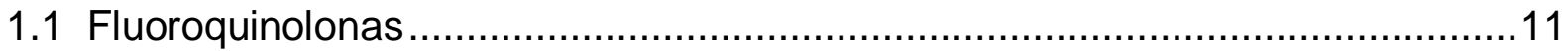

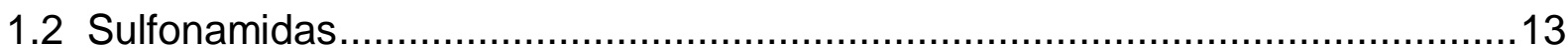

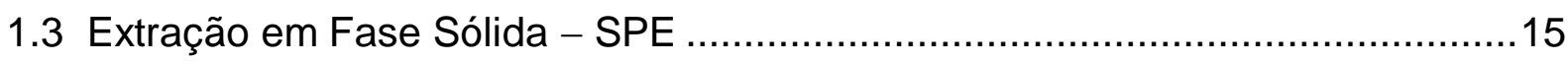

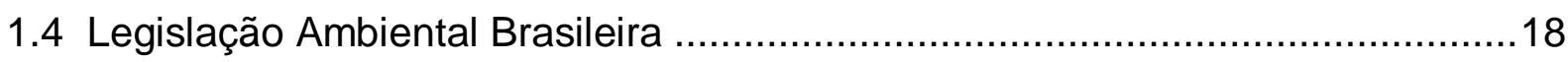

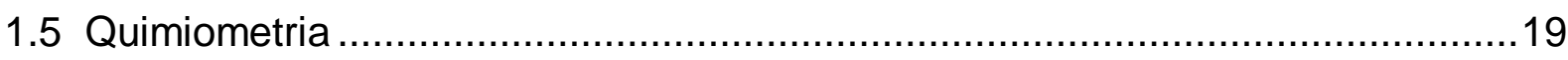

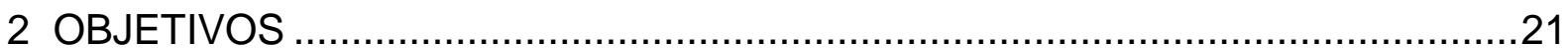

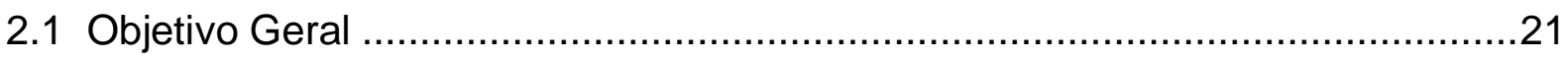

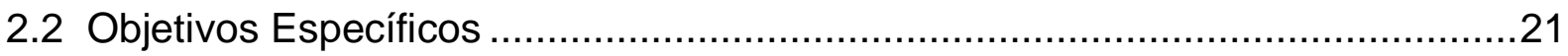

3 METODOLOGIA

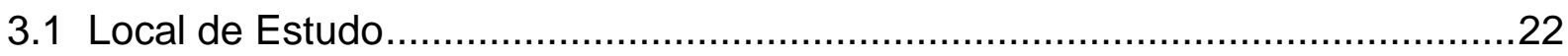

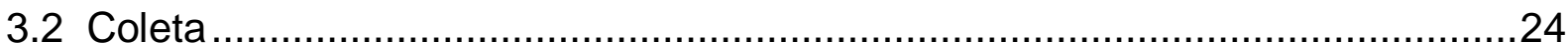

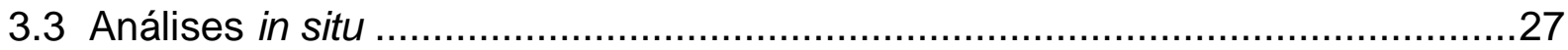

3.4 Determinação de quimioterápicos antimicrobianos …........................................28

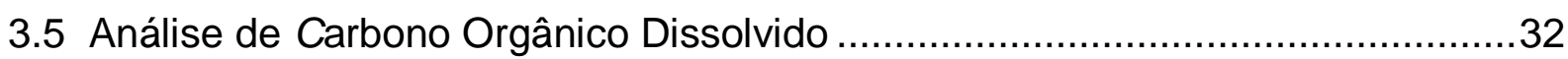

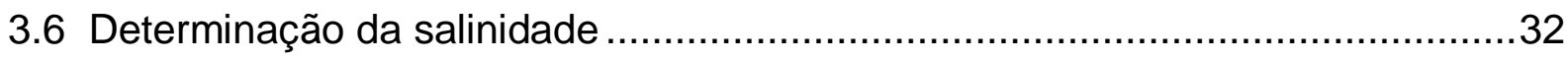

3.7 Concentração de saturação de oxigênio dissolvido ..........................................33

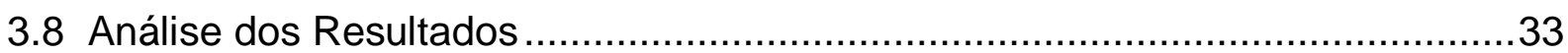

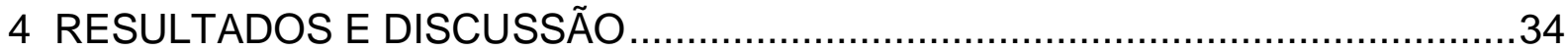

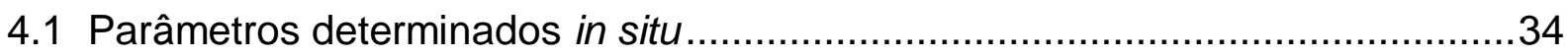

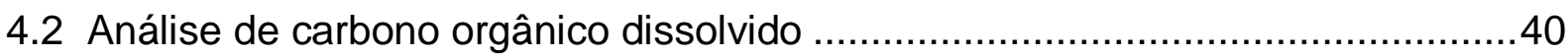

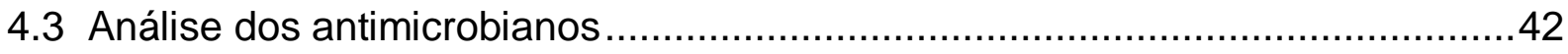

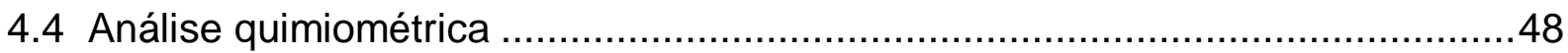

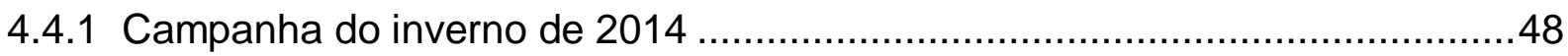

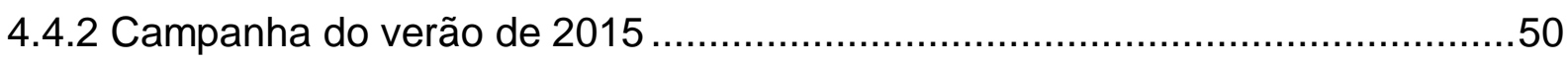

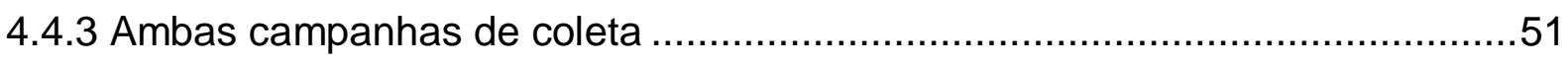

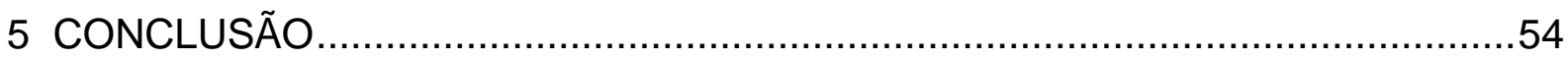

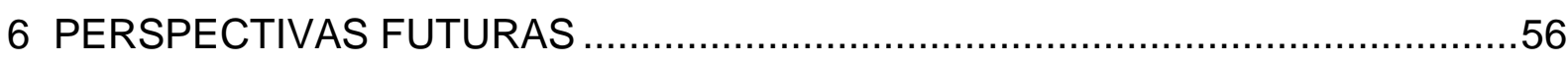

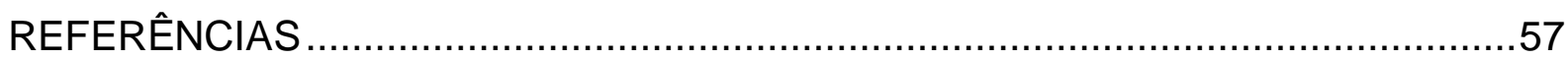




\section{INTRODUÇÃO}

Ultimamente há um elevado interesse no monitoramento de fármacos residuais, pois a poluição causada por estes compostos em águas superficiais e subterrâneas está se tornando reconhecida e já desperta uma preocupação ambiental. A indústria farmacêutica busca por princípios ativos mais eficazes através da concepção de uma maior potência, biodisponibilidade e resistência à degradação (KHETAN; COLLINS, 2007) e tais compostos já são encontrados, em baixas concentrações, em efluentes de estações de tratamento de esgoto e em águas naturais (GÖBEL et al., 2007; GRACIA-LOR et al., 2012; GUERRA et al., 2014.). Em 2002, um estudo do US Geological Survey (USGS) analisou a presença de fármacos e produtos para cuidados pessoais em várias localizações de 139 rios em 30 estados nos Estados Unidos da América e detectou, em cerca de 80\% destes, uma ampla gama de compostos biologicamente ativos, até mesmo em áreas remotas (KHETAN; COLLINS, 2007).

Dentre estes poluentes se destacam os antimicrobianos, considerados contaminantes emergentes, que são novos produtos químicos que ainda não constam nas legislações ambientais vigentes e cujo efeito no ambiente e na saúde humana ainda são desconhecidos (DEBLONDE et al. 2011). Eles são de extrema importância e indispensáveis no tratamento de sérias infecções, mas seu uso indiscriminado oferece riscos à saúde humana e ao meio ambiente, pois micro-organismos infecciosos estão se tornando resistentes aos fármacos antimicrobianos existentes (MARTINEZ, 2009).

A utilização generalizada de antimicrobianos para o tratamento de doenças em humanos e animais e para o crescimento na pecuária e na aquicultura são as principais causas da geração de populações bacterianas resistentes (RAHMAN et al., 2009; ABRAHAM et al., 2007; BORG et al., 2010). Estima-se que a resistência antimicrobiana é diretamente responsável por 23 mil mortes anualmente somente nos Estados Unidos e, 25 mil mortes na União Europeia. (CDC. 2013; ECDC, 2009) além de gerar gastos anuais de aproximadamente 55 bilhões de dólares nos Estados Unidos - 20 bilhões com os custos dos serviços de saúde e 35 bilhões com perdas de produtividade (SMITH; COAST, 2013). 
A preocupação com a ocorrência, destino no ambiente e efeitos nocivos destes contaminantes têm gerado diversas pesquisas em matrizes ambientais. Segundo Zou et al. (2011), pesquisas anteriores demonstraram que estações de tratamento de esgoto não são eficientes na remoção de antimicrobianos e que resíduos farmacêuticos são facilmente difundidos no meio aquático, razão pela qual as principais fontes de antimicrobianos em ambiente marinho são as descargas de rios, estações de tratamento de esgoto e maricultura. No Brasil há algumas pesquisas sobre a contaminação de ambientes aquáticos por antimicrobianos que detectaram tais compostos em efluente hospitalar (MARTINS et al., 2008) e água superficial de rio (LOCATELLI; SODRÉ; JARDIM, 2011).

Embora as regiões costeiras sejam consideradas receptoras de muitos contaminantes terrestres, estudos sobre a ocorrência e distribuição de antimicrobianos nestes ambientes são escassos e quase restritos ao Reino Unido (THOMAS; HILTON, 2004), China (XU et al., 2007; NA et al., 2011; ZOU et al., 2011; YANG et al., 2011), Estados Unidos (SINGH et al., 2010), Bélgica (WILLE et al., 2010), França (MUNARON et al., 2012), Índia (PANDA; PATRA; KAR, 2012) e Canadá (MEYER et al., 2008).

Nos trabalhos citados, destacam-se os quimioterápicos antimicrobianos fluoroquinolonas (FQs) e sulfonamidas (SAs), apesar de, segundo Zou et al. (2011), os tipos e concentrações de antimicrobianos detectados em diferentes áreas e países, possam variar de acordo com a prevalência das doenças, hábitos de tratamento ou, simplesmente, razões econômicas e mercadológicas. Esses antimicrobianos podem persistir em ambientes aquáticos por mais de um ano devido à hidrólise desses compostos, em pH neutro, ser lenta. O contrário acontece com os antibióticos $\beta$-lactâmicos que, embora sejam muito utilizados, degradam-se rapidamente em condições levemente ácidas ou básicas (KHETAN; COLLINS, 2007). A característica de serem persistentes no ambiente pode contribuir para a o acúmulo dos antimicrobianos Sas e FQs em ecossistemas marinhos. 


\subsection{Fluoroquinolonas}

Lesher e Cols (1962) descreveram o ácido nalidíxico que se tornou precursor das 4-quinolonas. Posteriormente, foram introduzidos dois outros compostos relacionados com o ácido nalidíxico, que são o ácido oxolínico e a cinoxacina (Figura 1), mas o interesse por este grupo de antimicrobianos diminuiu devido ao seu restrito espectro de atividade antibacteriana - maioria dos micro-organismos Enterobacteriaceae, Pseudomonas aeruginosa, estafilococos e estreptococos (WOLFSON; HOOPER, 1985) - e do rápido desenvolvimento de resistência (BERGAN, 1998).

Figura 1 - Precursores das quinolonas

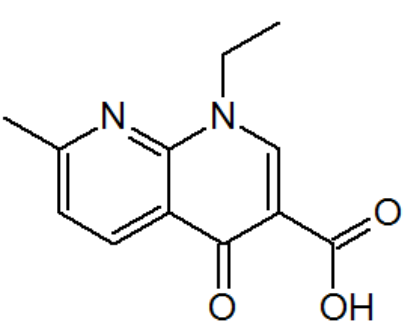

Ácido Nalidíxico

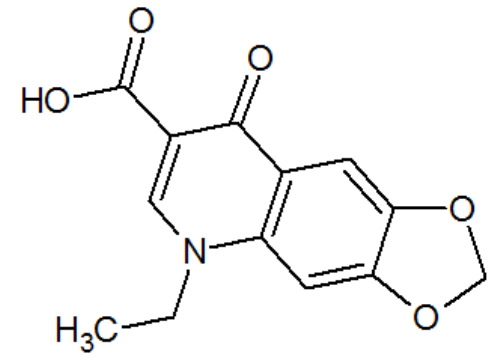

Ácido Oxolínico

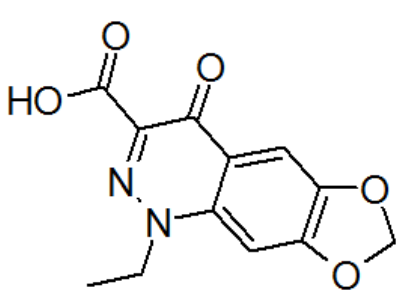

Cinoxacina

As fluoroquinolonas (Figura 2), são agentes antimicrobianos mais recentes e possuem maior espectro de ação. São ativas contra patógenos aeróbios Gramnegativos e de ação intermediária contra cocos Gram-positivos (WOLFSON; HOOPER, 1985). Agem diretamente na inibição da síntese do DNA. A inibição parece ocorrer pela interação da droga com complexos compostos de ácido desoxirribonucleico - DNA e duas outras enzimas-alvo, a DNA-girase e a topoisomerase IV, tal como uma armadilha de enzimas durante a reação de topoisomerização do DNA, formando uma barreira física à replicação, que resulta em morte celular (HOOPER, 2001). O espectro de ação das fluoroquinolonas inclui agentes patogênicos bacterianos que causam infecções urinárias, gastrointestinal, N. gonorrhoeae e certas bactérias que são difíceis de se tratar, como os bacilos multi-resistentes Gram-negativos 
e os resistentes à meticilina, por exemplo, o $S$. aureus (WOLFSON; HOOPER, 1985).

Figura 2 - Estrutura geral das fluoroquinolonas<smiles>[R1]N1CCN(c2cc3c(cc2F)c(=O)c(C(=O)O)cn3[R2])CC1</smiles>

Pensava-se que a resistência às fluoroquinolonas não era transmissível. Entretanto, hoje já se encontra genes de resistência às fluoroquinolonas, com frequência e no mundo todo (ADACHI, F. et al., 2013).

Em pesquisas para descoberta de como se dava a resistência às fluoroquinolonas, não foram encontrados nos micro-organismos modificadores específicos ou enzimas capazes de degradar o fármaco. A resistência se dá por meio de mutações, onde o micro-organismo altera o alvo principal do fármaco e/ou altera a permeação do mesmo para que o antimicrobiano não chegue ao seu objetivo (WETZSTEIN; SCHMEER; KARL, 1997).

As fluoroquinolonas são degradadas rapidamente quando expostas à luz solar e UV. Lin et al. (2010) demonstraram que a fotodegradação, especialmente por irradiação natural, resultou em quedas bruscas na concentração de enrofloxacina e ciprofloxacina em água e sedimentos, onde a enrofloxacina atingiu o $\mathrm{DT}_{50}$ (tempo para que $50 \%$ da concentração inicial seja dissipada) em 0,01 dia e não foi detectada após 4 dias, obedecendo a uma cinética de degradação de segunda ordem. Demonstraram que há também biodegradação, mas em menor proporção. 


\subsection{Sulfonamidas}

Derivadas da sulfanilamida (Figura 3), as sulfonamidas são conhecidas desde 1940 e estima-se que, desde então, mais de 150 compostos desta classe são aplicados como antimicrobianos na medicina humana e veterinária (BARAN et al., 2011).

Figura 3 - Estrutura da sulfanilamida<smiles>CNS(=O)(=O)c1ccc(N)cc1</smiles>

As sulfonamidas (Figura 4) são antimicrobianos bacteriostáticos sintéticos que possuem ação contra diversos organismos Gram-positivos e Gram-negativos. Esses antimicrobianos atuam como inibidores competitivos de ácido $\rho$-aminobenzóico no ciclo de metabolismo do ácido fólico, e assim inibem a multiplicação das bactérias. São constituídas de um anel benzênico, um grupo amina $\left(-\mathrm{NH}_{2}\right)$ e um grupo sulfonamida $\left(-\mathrm{SO}_{2} \mathrm{NH}_{2}\right)$, sendo que os grupos amina e sulfonamida devem estar na posição para em relação um ao outro para que a sulfonamida possua propriedades antibacterianas (SARMAH; MEYER; BOXALL, 2006).

Figura 4 - Estrutura geral das sulfonamidas<smiles>[R]NS(=O)(=O)c1ccc(N)cc1</smiles> 
Sulfonamidas são moléculas polares com propriedades anfóteras, protonadas abaixo de pH 2 ou 3 (QIANG; ADAMS, 2004). Apresentam baixa massa molar, entre 170 - $300 \mathrm{~g} \mathrm{~mol}^{-1}$, são solúveis em água e possuem baixa constante de Henry (BARAN et al., 2011). Segundo Sarmah, Meyer e Boxall (2006), embora sejam anfóteras, no organismo comportam-se como ácidos fracos e a solubilidade de um mesmo composto pode variar com alterações de $\mathrm{pH}$; portanto, defende-se que as propriedades farmacocinéticas destes compostos não podem ser discutidas como um grupo homogêneo, diferentemente do que acontece com suas propriedades antimicrobianas.

Os compostos veterinários mais utilizados dentro deste grupo são: sulfadiazina/trimetoprim, sulfadimetoxina, sulfametazina, sulfatiazol e sulfadimetoxina/ormetoprim. Também há outros que têm sido utilizados no gado, como sulfametoxazol e sulfacloropiridazina (SARMAH; MEYER; BOXALL, 2006). A amida ligada ao enxofre (N1) é desprotonada na faixa $5,5>\mathrm{pH}>7$. A amina ligada ao anel aromático (N4) é protonada em pH 2,5. Portanto, a maioria das sulfonamidas são carregados positivamente em condições ácidas, neutras entre $\mathrm{pH} 2,5$ e 6, e negativamente em condições alcalinas (HALLER et al., 2012).

Figura 5 - Localização das aminas N1 e N4 nas sulfonamidas

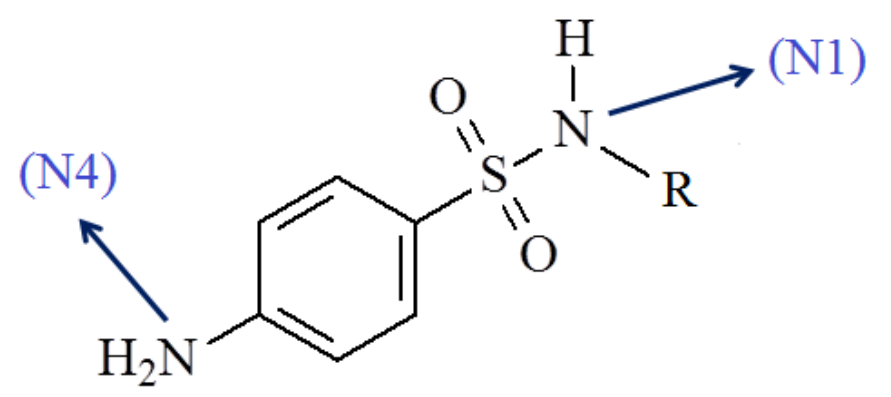

$\mathrm{Na}$ Europa, estima-se que no ano de 2000 foram usados $20.561 \mathrm{~kg}$ de sulfonamidas na agricultura; nos EUA, em 1999, calcula-se o uso de 9,3 $\times 10^{6} \mathrm{~kg}$ de antimicrobianos, 2,3\% deles sendo sulfonamidas (SARMAH; MEYER; BOXALL, 2006). As sulfonamidas são estáveis em presença de luz solar e em altas temperaturas; seu tempo de meia-vida, $t_{1 / 2}$, é maior que 1 ano. São persistentes no ambiente e encontradas no efluente das estações de tratamento, fatores que colaboram com a preocupação do uso indiscriminado destas substâncias (BARAN et al., 2011). 


\subsection{Extração em Fase Sólida - SPE}

Em análises que envolvem separação cromatográfica de compostos presentes em matrizes complexas é comum a presença dos analitos de interesse em nível de traços, $\mu \mathrm{g} \mathrm{L}^{-1}$ até $n g \mathrm{~L}^{-1}$, de inúmeros interferentes e compostos que podem prejudicar as colunas cromatográficas, tais como proteínas (JARDIM, 2010; QUEIROZ; COLLINS; JARDIM, 2001).

Tais dificuldades deixam em evidência a necessidade de um preparo de amostra que "limpe", ou seja, elimine os interferentes e, ao mesmo tempo, concentre os analitos de interesse fazendo com que sejam detectados e quantificados pelos métodos de análises conhecidos. Diversas técnicas já são conhecidas, tais como: extração líquido-líquido, extração em fluido supercrítico, extração em fase sólida e até modernizações destas técnicas como SPME (Micro Extração em Fase Sólida), e sistemas automatizados "on-line". Elas permitem que matrizes complexas não sejam uma barreira intransponível e que as análises sejam realizadas com eficiência.

A escolha da técnica de preparo de amostra depende da natureza da amostra, da matriz (estado físico, pH, teor de matéria orgânica, gorduras, proteínas etc.), das características do analito (propriedades físicas e químicas, tais como: massa molar, carga, polaridade, pKa) e da técnica analítica utilizada na determinação. Portanto, a escolha da técnica adequada de preparo de amostra é um fator determinante na confiabilidade dos resultados (JARDIM, 2010).

A SPE é umas das técnicas de extração mais utilizadas, porém apresenta algumas limitações, tal como o uso frequente de solventes tóxicos na etapa de dessorção do analito de interesse (BARRIONUEVO; LANÇAS, 2001).

$\mathrm{Na}$ SPE, os analitos presentes em uma matriz são extraídos juntamente com os compostos interferentes, ao percolarem por um cartucho contendo uma fase sólida sorvente. Utiliza-se um solvente para remover os interferentes da fase do cartucho e um outro solvente é utilizado para remover (eluir) os analitos de interesse. Este eluato é então coletado para a análise. 
Em geral, o procedimento da SPE é feito em quatro etapas, sendo elas: condicionamento da fase sólida; passagem da amostra pelo cartucho; lavagem ou clean-up; eluição do analito ou dos analitos (JARDIM, 2010).

A etapa de condicionamento da fase sólida destina-se à ativação do material do cartucho para uma interação efetiva com o analito. Adiciona-se um solvente de acordo com o material utilizado como fase estacionária e com o analito. É importante que o cartucho não seque para que não se formem caminhos preferenciais, que comprometeriam a reprodutibilidade do método.

Em seguida, a amostra é introduzida no cartucho com uma vazão controlada por um sistema de vácuo (sistemas manifold). Essa vazão deve ser controlada para que se obtenham resultados reprodutíveis. A quantidade de amostra a utilizada deve ser suficiente para se ter $\mathrm{o}$ analito em concentrações acima do limite de detecção do método analítico a ser utilizado.

A etapa de lavagem (clean-up) tem como objetivo eliminar os interferentes com um solvente que não tenha afinidade química suficiente para eluir o analito de interesse.

$\mathrm{Na}$ etapa de eluição do analito, utiliza-se um solvente com maior afinidade química com o analito do que o utilizado na etapa anterior de lavagem, para que o analito seja liberado da fase sólida. O ideal é eluir o analito com um baixo volume de solvente, pois com isso concentra-se a amostra. A

Figura 6 desmontra de maneira ilustrativa as etapas envolvidas na SPE.

Em casos nos quais os analitos estão presentes em concentrações muito baixas, pode-se acrescentar uma etapa ao processo, que é a etapa de secagem e ressuspensão. Esta etapa consiste em secar o eluato com um fluxo suave de um gás inerte como o nitrogênio e ressuspendê-lo em baixo volume para aumentar o fator de concentração do processo em geral. 
Figura 6 - Etapas da Extração em Fase Sólida (SPE, do inglês Solid-Phase Extraction).

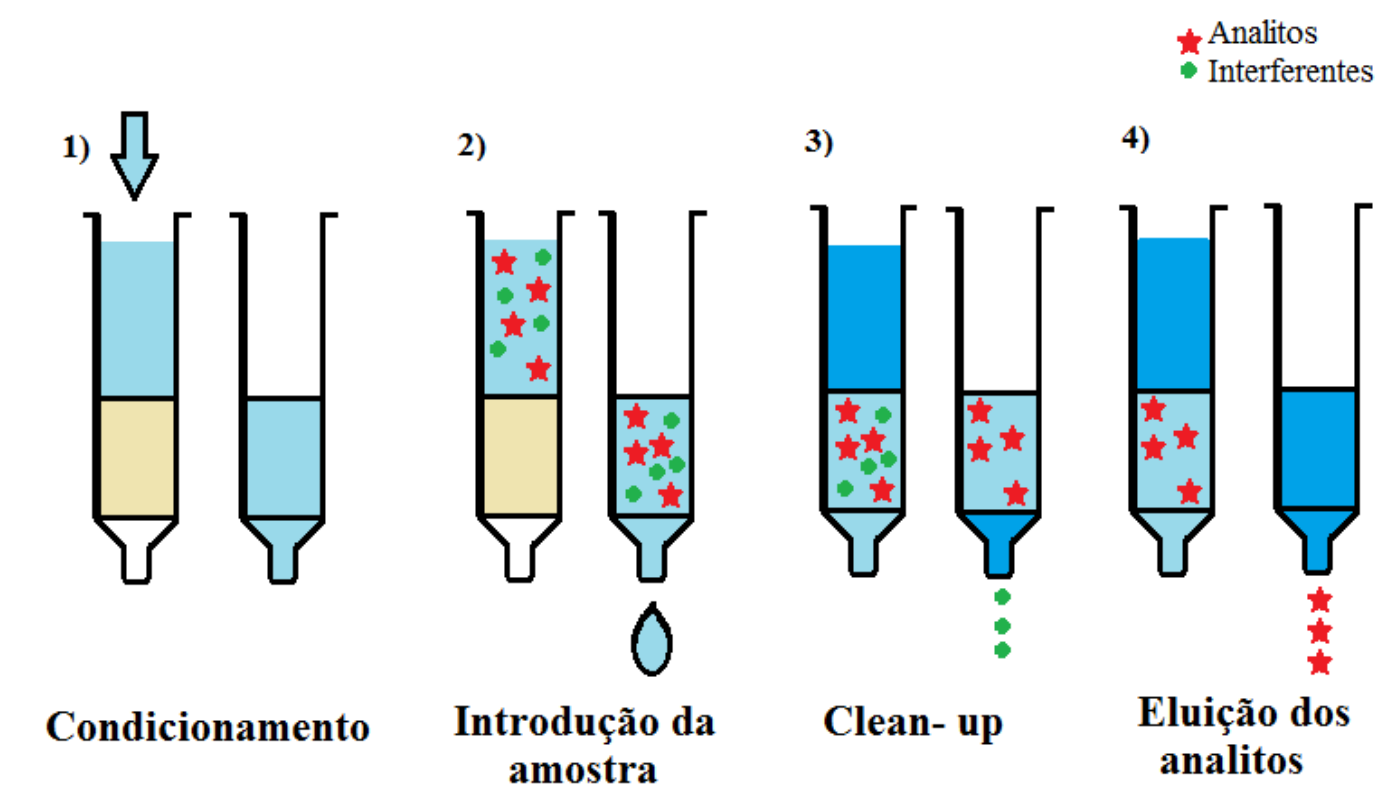

Os mecanismos de separação na SPE são similares aos da cromatografia líquida, devido ao fato das fases sólidas utilizadas nas duas técnicas também serem similares. Os principais mecanismos são: adsorção, partição, exclusão e troca iônica (LANÇAS, 2004).

A maioria dos sorventes, ou fases sólidas utilizadas, baseiam-se em grupos orgânicos C2, C8, C18, cicloexil, fenil, cianopropil, aminopropil, ligados quimicamente à sílica. Outros sorventes apresentam fases poliméricas (como o carbono grafitizado e sorventes de modo mistos), ou outras modificações podem ser feitas para maior eficiência de acordo com as características dos analitos e das matrizes em cada caso. Geralmente, a escolha da fase/sorvente correta segue as mesmas regras aplicadas à cromatografia líquida de alta eficiência (CLAE), onde se analisa primeiramente as características químicas do analito, propriedades do sorvente e a composição da matriz. Um bom modo de garantir a seletividade do sorvente é analisar grupos funcionais do analito que não estão presentes na matriz e nos interferentes (JARDIM, 2010).

Em 1996, a Waters introduziu no mercado a fase Oasis HLB, constituída por um copolímero Hidrofílico-Lipofílico balanceado de fase reversa, um sorvente para compostos ácidos, básicos e neutros. A Figura 7 apresenta a estrutura do sorvente HLB. 
Figura 7 - Estrutura da Fase Oasis HLB ${ }^{\circledR}$ (Waters).

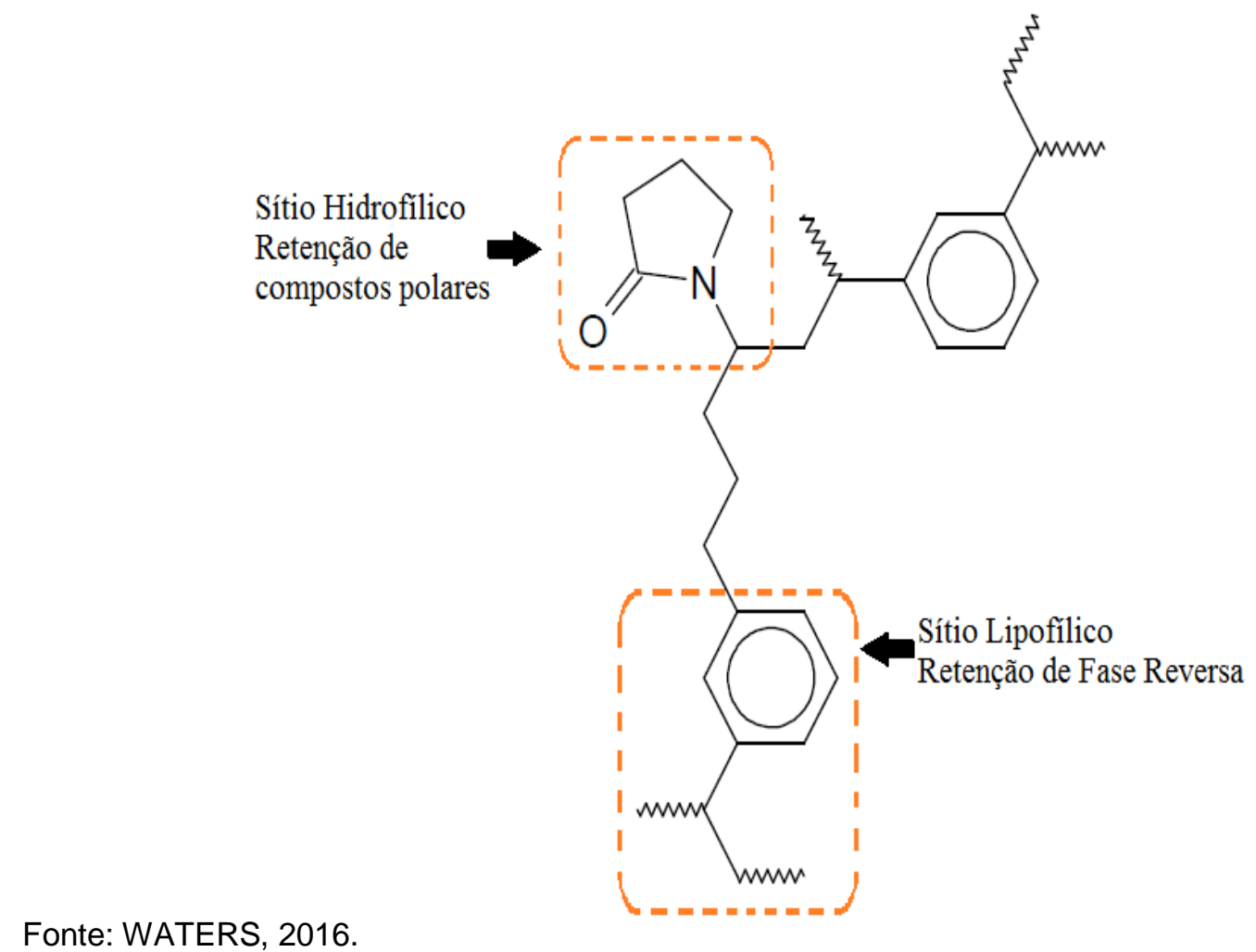

Este sorvente é um polímero hidrofílico a base de estireno modificado, desenvolvido para extrair vários compostos de amostras aquosas. Seu mecanismo de retenção é predominantemente por fase reversa e como a parte hidrofílica é modificada, também é seletivo para compostos mais polares (SIGMA-ALDRICH, 2016).

O sorvente HLB se mostra muito eficiente no "clean-up" de matrizes complexas e na recuperação dos analitos. Por esse motivo, se encontra facilmente o uso desta fase em análises de amostras de águas de rio e de mar, tal como nos trabaIhos de Xu et al. (2007), Chen et al. (2013), Na et al. (2011), Yan et al. (2013) e Zhang et al. (2012).

\subsection{Legislação Ambiental Brasileira}

No âmbito Federal, a lei no 6.938, de 31 de agosto de 1981, estabelece a Política Nacional do Meio Ambiente, constitui o Sistema Nacional do Meio Ambiente, cria 
o Conselho Nacional do Meio Ambiente e institui o Cadastro Técnico Federal de Atividades e Instrumentos de Defesa Ambiental. A Política Nacional do Meio Ambiente considera o meio ambiente um patrimônio público a ser necessariamente assegurado e protegido, visa assegurar condições ao desenvolvimento sócio-econômico, os interesses da segurança nacional e a proteção da dignidade da vida humana em nosso país.

Segundo a lei n 6938/81, os órgãos e entidades da União, bem como dos Estados, municípios e fundações instituídas pelo poder público, são responsáveis pela proteção e melhoria da qualidade ambiental e constituem o Sistema Nacional do Meio Ambiente (SISNAMA). Este tem como órgão superior o Conselho Nacional do Meio Ambiente (CONAMA), com a função de assistir ao Presidente da República na formulação de diretrizes da Política Nacional do Meio Ambiente.

A Resolução do CONAMA no 357 de 17 de março de 2005 dispõe sobre a classificação e diretrizes ambientais para o enquadramento dos corpos d'água superficiais. Esta resolução esbelecia as condições e padrões de lançamento de efluentes e foi alterada parcialmente e completada pela Resolução CONAMA ํo 430/11. O enquadramento das águas superficiais doces, salobras e salinas é baseado não necessariamente no seu estado atual, mas nos níveis de qualidade que deveriam possuir.

Essa resolução é referência para pesquisas acadêmicas, que geralmente realizam uma comparação entre os resultados obtidos e os limites fixados para as variáveis estabelecidas para a classificação da qualidade das águas, porém isso traz uma visão pontual da qualidade dos corpos d'água.

\subsection{Quimiometria}

A investigação de antimicrobianos como micropoluentes aquáticos envolve a análise de grande quantidade de dados, podendo ser mal interpretados devido à sua complexidade. Neste contexto, faz-se importante o uso da Quimiometria, que faz uma abordagem multivariada (SIMEONOV; STEFANOV; TSAKOVSKI, 2000) e con- 
sidera a correlação entre as variáveis analisadas simultaneamente, permitindo a extração de uma maior quantidade de informações (SENA et al., 1999).

Os métodos quimiométricos são ferramentas importantes para revelar e avaliar relações complexas e obter informações significativas frente ao grande número de dados nas análises ambientais. A análise quimiométrica é utilizada a fim de revelar os padrões significativos, à procura de possíveis variáveis, fontes de variações, agrupamentos e distribuição espacial e temporal do grande conjunto de dados obtidos. A análise de clusters (CA) e a análise por componentes principais (PCA) são os métodos quimiométricos mais utilizados para o agrupamento dos dados obtidos, permitindo estudar a distribuição de produtos farmacêuticos com concentrações semelhantes ao longo das estações de amostragem e/ou encontrar relações entre cargas ambientais de fármacos e as características da estação de amostragem (ALODAINI et al., 2012.).

A análise de clusters, possui um propósito descritivo e consiste em um procedimento de análise de dados onde é gerado uma classificação entre os objetos (no nosso caso de estudo, pontos de amostragem), onde são gerados subconjuntos dispostos em níveis ordenados em forma de similaridade (KÖHN; HUBERT, 2006). 


\section{OBJETIVOS}

\subsection{Objetivo Geral}

Investigar a ocorrência e avaliar a distribuição espaço-temporal dos quimioterápicos antimicrobianos das classes das Fluoroquinolonas e Sulfonamidas na Baía de Itaguá em Ubatuba/SP, usando técnicas quimiométricas como ferramentas de interpretação.

\subsection{Objetivos Específicos}

$\checkmark$ Desenvolver um método analítico empregando Extração em Fase Sólida (SPE) e Cromatografia Líquida de Alta Eficiência acoplada à Espectrometria de Massas (CLAE-MS/MS) para a análise qualitativa e quantitativa de quimioterápicos antimicrobianos em águas superficiais (continentais e costeiras).

$\checkmark$ Determinar as características físico-químicas: $\mathrm{pH}$, temperatura, oxigênio dissolvido e potencial redox, além do Carbono Orgânico Dissolvido (COD) nos pontos de amostragem.

$\checkmark$ Usar técnicas quimiométricas para a avaliação espaço-temporal de quimioterápicos antimicrobianos no ecossistema estudado. 


\section{METODOLOGIA}

\subsection{Local de Estudo}

A cidade de Ubatuba é uma estância balneária localizada no litoral norte do Estado de São Paulo. Segundo o último censo, sua população em 2010 era de 78.801 hab, com uma estimativa de 85.399 hab para 2014 (IBGE, 2012a). Ainda em 2010, a densidade demográfica era de 110,87 hab/ $\mathrm{km}^{2}$, contrastando com 22,43 hab/ $\mathrm{km}^{2}$ para o Brasil (IBGE, 2012b). Durante o verão, a população aumenta de dez a doze vezes (SJDC, 2012), pressionando ainda mais os ecossistemas aquáticos.

Os rios Acaraú, Lagoa-Tavares, Grande e Indaiá deságuam na Baía de Ubatuba e comprometem a qualidade sanitária das águas, devido à entrada de esgoto não tratado (CETESB, 2011). Segundo Muniz, Pires-Vanin e Venturini (2013), o regime de chuvas também exerce influência na qualidade das águas e possui maior contribuição no verão.

O Rio Acaraú pode ser tomado como exemplo do que acontece com os rios estudados. Ele faz parte da bacia hidrográfica do Rio Grande, sendo sua nascente no Parque Estadual da Serra do Mar. Ao cruzar a cidade de Ubatuba, passa pelos bairros de Sesmaria, Estufa II, Praia Grande, Itaguá, Acaraú e Tenório até desaguar no canto direito da praia do Itaguá. O rio sofre com o despejo de esgoto doméstico e com a deposição de lixo e entulho em suas margens, problema que é visto nos quatro rios. O avanço urbano destruiu a mata ciliar e, em alguns lugares, invade a margem.

A CETESB (2015) lançou um relatório sobre a qualidade das águas superficiais do estado de São Paulo no ano de 2014. Segundo este relatório, a cidade de Ubatuba possui nota 4,10, numa escala que vai de 0 a 10, no ICTEM (Indicador de Coleta e Tratabilidade de Esgoto do Município) que retrata uma situação que leva em consideração a efetiva remoção da carga orgânica em relação à carga orgânica potencial gerada pela população urbana. O Rio Acaraú teve uma média anual de 36, numa escala de 0 a 100 no índice de qualidade das águas (IQA), o que é consi- 
derado como ruim; o Rio Lagoa Tavares e o Rio Indaiá tiveram um IQA médio anual de 74 e 71, respectivamente, o que é considerado como bom; e o Rio Grande teve um IQA médio anual de 56, 76 e 78, nos seus três pontos de amostragem, também considerado como bom. Segundo este mesmo relatório, sobre a qualidade das águas salinas e salobras do estado de São Paulo, a Baía de Itaguá apresentou um IQA médio no ano de 2014 igual a 90, o que é considerado bom; porém, vale destacar que os pontos de amostragem foram distantes das foz dos rios, principais comprometedores da qualidade das águas na baía.

A SABESP é responsável pelo serviço de água e esgoto em Ubatuba desde 1975 (SABESP, 2016a). A captação de água é feita por cinco sistemas e gera $843 \mathrm{~L}$ $\mathrm{s}^{-1}$. O tratamento de esgotos é realizado por cinco sistemas, três estações de tratamento e duas de pré-condicionamento — Ipiranguinha, Principal, Toninhas, Taquaraí e Enseada - com capacidade de $325 \mathrm{~L} \mathrm{~s}^{-1}$. Nos últimos anos foram investidos $\mathrm{R} \$ 572$ milhões em obras de saneamento nas cidades do litoral norte do estado de São Paulo (SABESP, 2016b), mas ainda não é o suficiente para o tratamento de todo o esgoto sanitário gerado.

Os sedimentos mais internos da baía, perto da foz dos rios, são formados por silte e uma areia muito fina e com moderado teor de matéria orgânica (BURONE; PIRES-VANIN, 2006). Segundo Muniz et al. (2005), esta região interna da baía de Ubatuba encontra-se de leve a moderadamente poluída por metais tóxicos, hidrocarbonetos e esteroides. Este fato ainda é observado nos relatórios sobre a qualidade das águas no ano de 2014 (CETESB, 2015). Este local representa um possível receptor de diversas classes de fármacos destinadas a humanos e também ao uso veterinário.

As amostragens foram realizadas na Baía de Itaguá e nos quatro rios que nela desembocam, nomeadamente Rio Indaiá, Rio Grande, Rio Lagoa-Tavares e Rio Acaraú, localizados na cidade de Ubatuba, no litoral norte do estado de São Paulo (Figura 8). A entrada de sedimentos fluviais é fortemente dependente do regime de chuvas, com elevadas contribuições durante o verão (MAHIQUES; TESSLER; FURTADO, 1998). A qualidade das águas é influenciada pelos quatro rios que deságuam na região (CETESB, 2010). 
Figura 8 - Imagem da Baía de Itaguá em Ubatuba e pontos de amostragem.

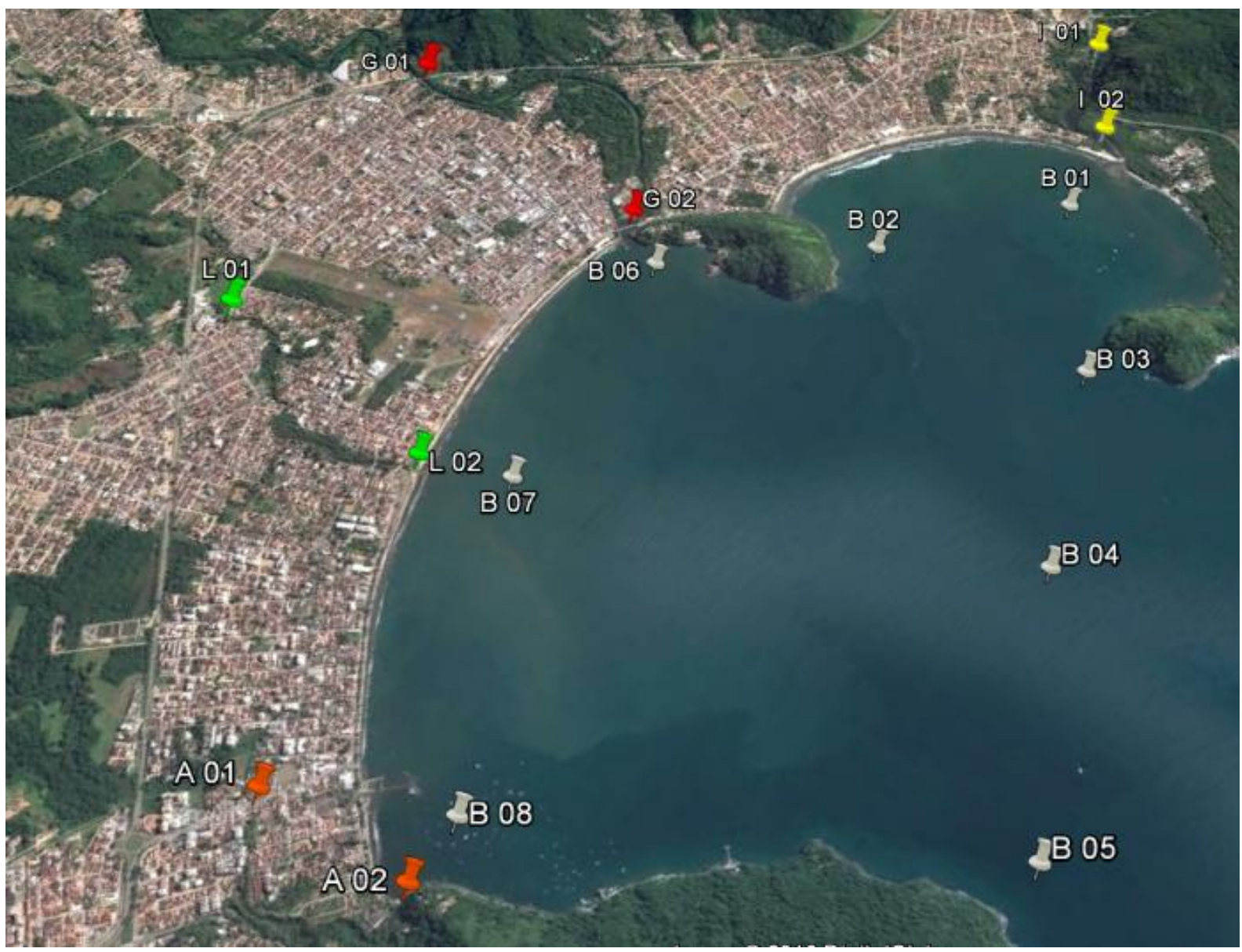

Fonte: GOOGLE Earth, versão 7.1.4.1529: Google Inc., 2015.

\subsection{Coleta}

As amostragens seguiram os padrões estabelecidos no Guia Nacional de Coleta e Preservação de Amostras (ANA; CETESB, 2011).

As coletas foram realizadas em duas campanhas para abranger duas estações climáticas e investigar uma possível variação sazonal dos pontos de amostragem. Os pontos de coleta foram escolhidos de modo que fosse investigada a contaminação dos corpos d'água ao longo do seu curso natural e também de maneira que fossem de fácil acesso. 
A primeira campanha foi realizada no início do mês de setembro de 2014 , correspondendo ao final da estação de seca (inverno) e a segunda no final do mês de fevereiro, correspondendo ao final da estação chuvosa (verão).

Um total de 32 amostras de água superficial foram analisadas, sendo 8 pontos de amostragem nos rios Acaraú (A_01 e A_02), Lagoa-Tavares (L_01 e L_02), Grande (G_01 e G_02) e Indaiá (I_01 e I_02) e 8 pontos na Baía de Itaguá em Ubatuba (B_01, B_02, B_03, B_04, B_05, B_06, B_07 e B_08), todos georreferenciados (Tabela 1).

Tabela 1 - Georreferenciamento dos pontos de coleta: (I) Rio Indaiá, (G) Rio Grande, (L) Rio LagoaTavares, (A) Rio Acaraú e (B) Baía de Itaguá em Ubatuba.

\begin{tabular}{|c|c|c|c|}
\hline Amostras & Latitude (S) & Longitude(W) & OBS \\
\hline I_01 & $23^{\circ} 24.717^{\prime}$ & $45^{\circ} 03.455^{\prime}$ & $\begin{array}{l}\text { Coleta sob a ponte na estrada Rio- } \\
\text { Santos }\end{array}$ \\
\hline I_02 & $23^{\circ} 24.963^{\prime}$ & $45^{\circ} 03.226^{\prime}$ & Próximo à foz do rio \\
\hline G_01 & $23^{\circ} 25.863^{\prime}$ & $45^{\circ} 05.008^{\prime}$ & $\begin{array}{l}\text { Coleta sob a ponte na estrada Rio- } \\
\text { Santos }\end{array}$ \\
\hline G_02 & $23^{\circ} 25.947^{\prime}$ & $45^{\circ} 04.146^{\prime}$ & $\begin{array}{l}\text { Coleta sob a ponte perto do farol, na } \\
\text { foz do rio }\end{array}$ \\
\hline L_01 & $23^{\circ} 26.724^{\prime}$ & $45^{\circ} 04.797^{\prime}$ & Logo a jusante de uma comunidade \\
\hline L_02 & $23^{\circ} 26.793^{\prime}$ & $45^{\circ} 04.053^{\prime}$ & $\begin{array}{c}\text { Sob uma passarela de pedestres e } \\
\text { bicicletas }\end{array}$ \\
\hline A_01 & $23^{\circ} 27.578^{\prime}$ & $45^{\circ} 03.720^{\prime}$ & $\begin{array}{l}\text { Sob uma ponte. Construções inva- } \\
\text { dem o rio. }\end{array}$ \\
\hline A_02 & $23^{\circ} 27.547^{\prime}$ & $45^{\circ} 03.299^{\prime}$ & Sob uma ponte. Região de mangue. \\
\hline B_01 & $23^{\circ} 25.136^{\prime}$ & $45^{\circ} 03.150^{\prime}$ & Em frente à foz do rio Itaguá \\
\hline B_02 & $23^{\circ} 25.586^{\prime}$ & $45^{\circ} 03.612^{\prime}$ & $\begin{array}{c}\text { Divisão das praias do Perequê- } \\
\text { mirim e de Itaguá }\end{array}$ \\
\hline B_03 & $23^{\circ} 25.544^{\prime}$ & $45^{\circ} 02.925^{\prime}$ & Saída da enseada (ponta esquerda) \\
\hline B_04 & $23^{\circ} 26.278^{\prime}$ & $45^{\circ} 02.405^{\prime}$ & Saída da enseada (centro) \\
\hline B_05 & $23^{\circ} 26.880^{\prime}$ & $45^{\circ} 02.120^{\prime}$ & Saída da enseada (ponta direita) \\
\hline B_06 & $23^{\circ} 25.997^{\prime}$ & $45^{\circ} 04.069^{\prime}$ & Em frente ao farol \\
\hline
\end{tabular}




$\begin{array}{llll}\text { B_07 } & 23^{\circ} 26.773^{\prime} & 45^{\circ} 03.952^{\prime} & \begin{array}{c}\text { Em frente à ponte do rio Lago- } \\ \text { ra_Tavares }\end{array} \\ \text { B_08 } & 23^{\circ} 27.477^{\prime} & 45^{\circ} 03.321^{\prime} & \text { Em frente à ponte do rio Acaraú }\end{array}$

As amostras destinadas à análise de quimioterápicos antimicrobianos foram coletadas em frascos de polietileno, que passaram por um processo de limpeza. As amostras destinadas à análise de carbono orgânico dissolvido foram coletadas em frascos de vidro âmbar de $100 \mathrm{~mL}$ e passaram pelo mesmo processo de limpeza. Esta limpeza consistiu em imergir os frascos e tampas em solução de detergente alcalino $0,1 \%$, mantendo-os assim por no mínimo 48 horas. A seguir foram esfregados com escovas e enxaguados com água deionizada inúmeras vezes, de modo a garantir que os analitos de interesse, se presentes, estivessem abaixo do limite de deteç̧ão do método analítico. Em seguida, foram postos com a boca para baixo sobre papel absorvente. Os frascos foram tampados, etiquetados e guardados. Após a coleta foi adicionado $1 \mathrm{~mL}$ de solução de $\mathrm{H}_{2} \mathrm{SO}_{4}$ (1:1) para preservar as amostras e no laboratório foram adicionados mais algumas gotas de modo que $0 \mathrm{pH}$ ficasse abaixo de 2 (ANA; CETESB, 2011).

As amostras foram coletadas com o auxílio de uma garrafa de van Dorn (Figura 9) a uma profundidade de 1 metro abaixo da lâmina d'água, salvo em alguns pontos cuja profundidade era menor que $1 \mathrm{~m}$. Após a coleta, os frascos foram guardados em caixa térmica com gelo. 
Figura 9 - Garrafa de van Dorn.

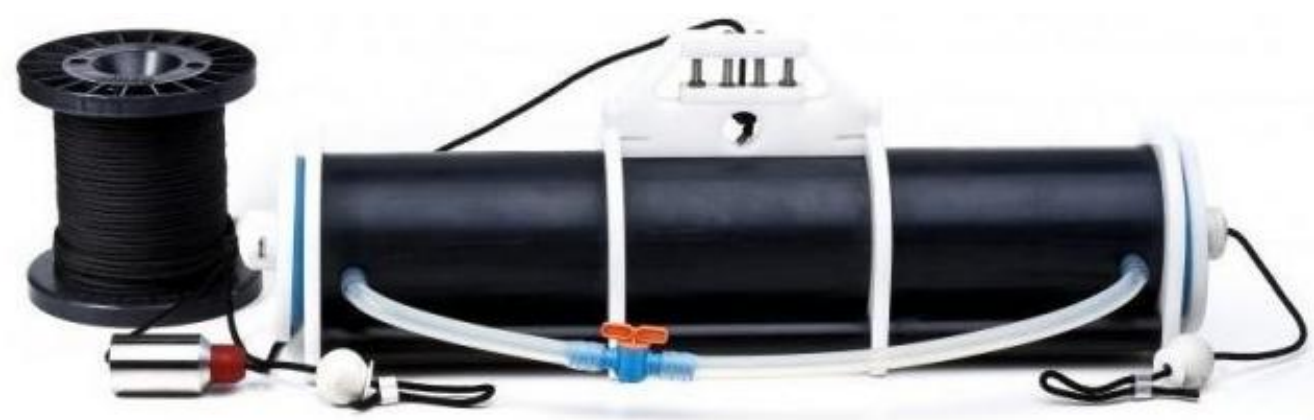

Fonte: SHOPPING DO LABORATÓRIO, 2016.

\subsection{Análises in situ}

Em campo, foi utilizada uma sonda paramétrica modelo Professional Plus da marca $\mathrm{YSI}^{\circledR}$ (Figura 10), para medir algumas variáveis físico-químicas da água: $\mathrm{pH}$, temperatura, oxigênio dissolvido e potencial redox.

Figura 10 - Sonda paramétrica YSI Professional Plus.

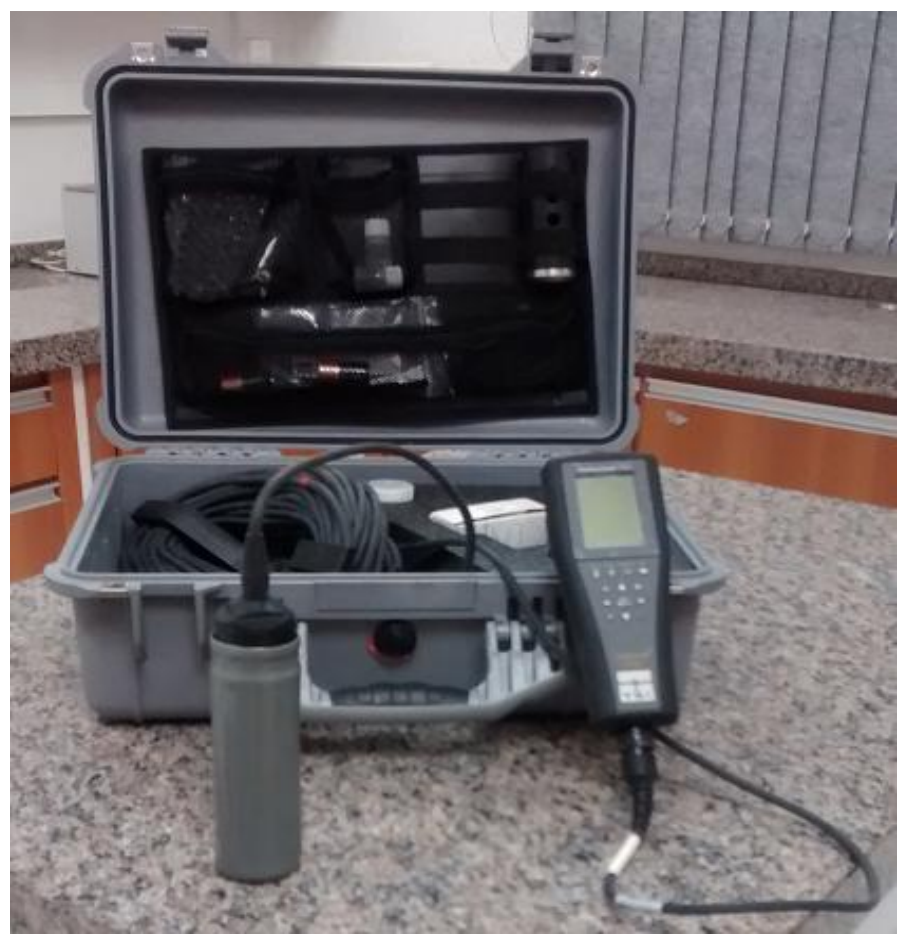




\subsection{Determinação de quimioterápicos antimicrobianos}

Os quimioterápicos pesquisados foram: sulfamerazina, sulfametazina, sulfatiazol, sulfametoxazol, sulfacloropiridazina, sulfametizol e sulfaquinoxalina (sulfonamidas); norfloxacina, ciprofloxacina, enrofloxacina e pefloxacina (fluoroquinolonas). Também foi pesquisada a presença de trimetoprima, pois é comumente ministrado com as sulfonamidas, totalizando 12 analítos, sendo 7 Sas e 4 FQs.

As Tabela 2 e 3 apresentam os quimioterápicos antimicrobianos que podem vir a ser detectados e quantificados, juntamente com algumas informações importantes. As fluoroquinolonas e as sulfonamidas são de uso predominantemente humano e veterinário, respectivamente.

Tabela 2 - Fluoroquinolonas pesquisadas.

Informações
- Nome: Ciprofloxacina
- Nome IUPAC: Ácido 1-ciclopropil-6-fluoro-4-
oxo-7-(piperazin-1-il)-quinolina-3-carboxílico
- No- CAS: 85721-33-1.
- Fórmula molecular: $\mathrm{C}_{17} \mathrm{H}_{18} \mathrm{FN}_{3} \mathrm{O}_{3}$
- Massa molar $=331,3415 \mathrm{~g} \mathrm{~mol}^{-1}$
- Solubilidade em água: $30 \mathrm{~g} \mathrm{~L}^{-1}\left(20^{\circ} \mathrm{C}\right)$
- Iog $\mathrm{P}=0,28$
- pK


<smiles>CCn1cc(C(=O)O)c(=O)c2cc(F)c(N3CCN(C)CC3)cc21</smiles>

- Nome: Pefloxacina

- Nome IUPAC: Ácido 1-etil-6-fluoro-7-(4metilpiperazin-1-il)-4-oxo-1,4-dihidroquinolina-3carboxílico

- № CAS: 70458-92-3

- Fórmula molecular: $\mathrm{C}_{17} \mathrm{H}_{20} \mathrm{FN}_{3} \mathrm{O}_{3}$

- Massa molar = $333.3579 \mathrm{~g} \mathrm{~mol}^{-1}$

- Solubilidade em água: $11,4 \mathrm{~g} \mathrm{~L}^{-1}\left(25^{\circ} \mathrm{C}\right)$

- $\log P=0,27$

- $\mathrm{pK}_{\mathrm{a}}=5,66$

Tabela 3 - Sulfonamidas pesquisadas.

\begin{tabular}{|c|c|}
\hline Estrutura química & Informações \\
\hline $\mathrm{H}_{2} \mathrm{~N}^{-}$ & $\begin{array}{l}\text { - Nome: Sulfametoxazol } \\
\text { - Nome IUPAC: 4-amino- } N-(5-m e t i l-1,2-o x a z o l-3- \\
\text { il)-benzeno-1-sulfonamida } \\
\text { - № CAS: } 723-46-6 \\
\text { - Fórmula molecular: } \mathrm{C}_{10} \mathrm{H}_{11} \mathrm{~N}_{3} \mathrm{O}_{3} \mathrm{~S} \\
\text { - Massa molar }=253,278 \mathrm{~g} \mathrm{~mol}^{-1} \\
\text { - Solubilidade em água: } 0,61 \mathrm{~g} \mathrm{~L}^{-1}\left(37^{\circ} \mathrm{C}\right) \\
\text { - log } \mathrm{P}=0,89 \\
\text { - } \mathrm{pK}_{\mathrm{a}}=6,16\end{array}$ \\
\hline $\mathrm{H}_{2} \mathrm{~N}^{\prime}$ & $\begin{array}{l}\text { - Nome: Sulfametazina } \\
\text { - Nome IUPAC: 4-amino- } \mathrm{N}-(4,6 \text {-dimetilpirimidin-2- } \\
\text { il) } \\
\text { benzeno-1-sulfonamida } \\
\text { - № CAS: } 57-68-1 \\
\text { - Fórmula molecular: } \mathrm{C}_{12} \mathrm{H}_{14} \mathrm{~N}_{4} \mathrm{O}_{2} \mathrm{~S} \\
\text { - Massa molar }=278.33 \mathrm{~g} \mathrm{~mol}^{-1} \\
\text { - Solubilidade em água: } 1,5 \mathrm{~g} \mathrm{~L}^{-1}\left(29^{\circ} \mathrm{C}\right) \\
\text { - log } \mathrm{P}=0,89 \\
\text { - } \mathrm{pK}_{\mathrm{a}}=7,59\end{array}$ \\
\hline $\mathrm{H}_{2} \mathrm{~N}^{\prime}$ & $\begin{array}{l}\text { - Nome: Sulfatiazol } \\
\text { - Nome IUPAC: 4-amino- } \mathrm{N}-(1,3 \text {-thiazol-2-il) } \\
\text { benzeno-1-sulfonamida } \\
\text { - № CAS: } 72-14-0 \\
\text { - Fórmula molecular: } \mathrm{C}_{9} \mathrm{H}_{9} \mathrm{~N}_{3} \mathrm{O}_{2} \mathrm{~S}_{2} \\
\text { - Massa molar = 255.317 } \mathrm{g} \mathrm{mol}^{-1} \\
\text { - Solubilidade em água: } 0,373 \mathrm{~g} \mathrm{~L}^{-1}\left(25^{\circ} \mathrm{C}\right) \\
\text { - log } \mathrm{P}=0,05 \\
\text { - } \mathrm{pK}_{\mathrm{a}}=7,2\end{array}$ \\
\hline
\end{tabular}

- Nome: Enrofloxacina

- Nome IUPAC: Ácido 1-cilcopropil-7-(4etilpiperazina-1-il)-6-fluoro-4-oxo-1,4dihidroquinolina-3-carboxil

- № CAS: 93106-60-6

- Fórmula molecular: $\mathrm{C}_{19} \mathrm{H}_{22} \mathrm{FN}_{3} \mathrm{O}_{3}$

- Massa molar $=359.395 \mathrm{~g} \mathrm{~mol}^{-1}$

- Solubilidade em água: $3,397 \mathrm{~g} \mathrm{~L}^{-1}\left(25^{\circ} \mathrm{C}\right)$

- $\log P=1,87$

- $\mathrm{pK}_{\mathrm{a}}=6,43$ 


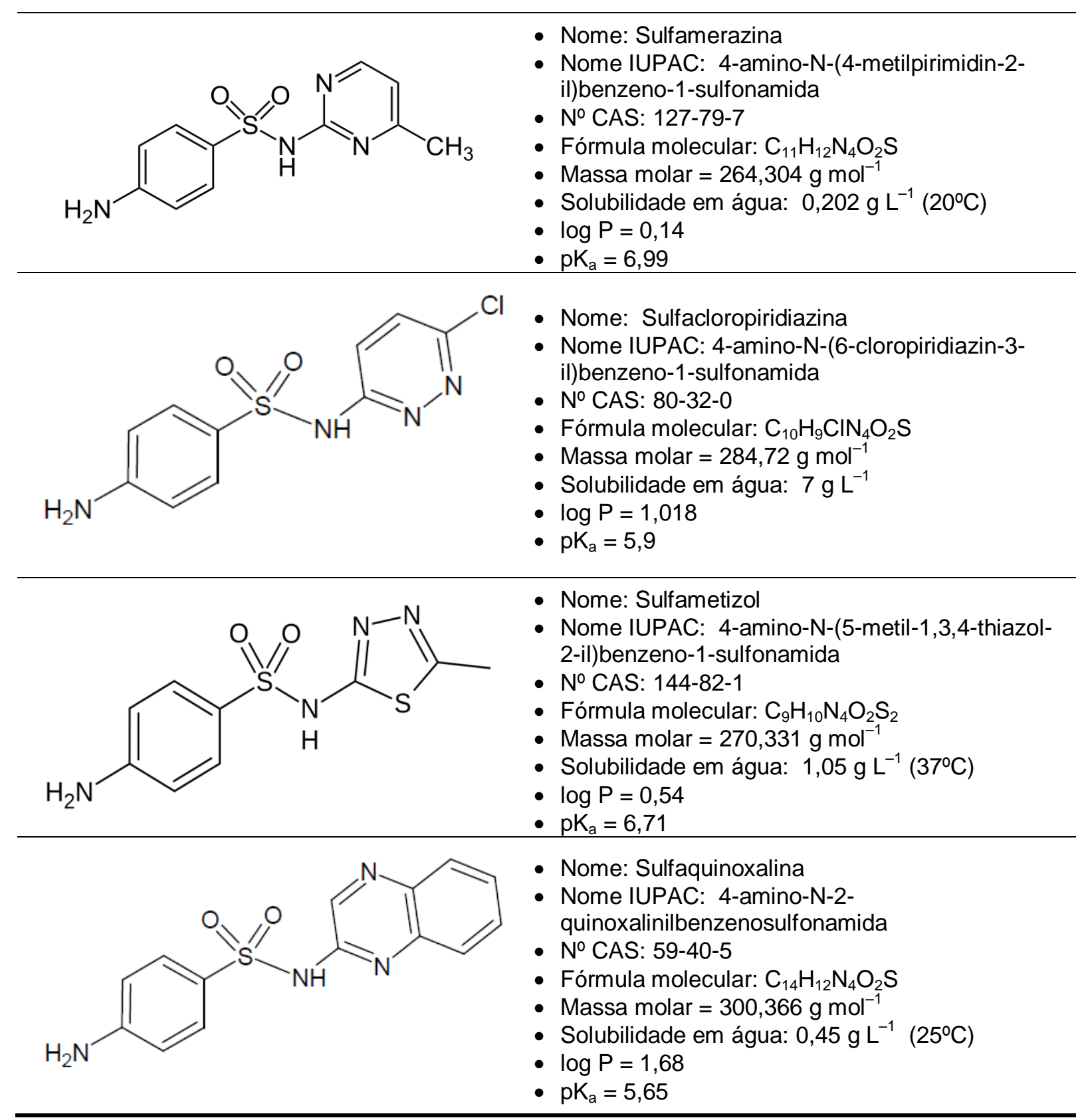

Para as determinações dos quimioterápicos, as amostras foram filtradas em membrana de 0,45 $\mu \mathrm{m}$ de porosidade. Posteriormente, foram acidificadas até $\mathrm{pH} 3$ com adição de $\mathrm{H}_{2} \mathrm{SO}_{4}$.

Para a extração em fase sólida (SPE), foram utilizados cartuchos Oasis HLB de $6 \mathrm{~mL}$ com $200 \mathrm{mg}$ de fase que foi condicionado com $6 \mathrm{~mL}$ de metanol e $6 \mathrm{~mL}$ de água destilada acidificada com $\mathrm{H}_{2} \mathrm{SO}_{4}$ até $\mathrm{pH}$ 3. Todos as etapas do procedimento de SPE foram realizadas com vazão de aproximadamente $10 \mathrm{~mL} \mathrm{~min}^{-1}$. 
Foi utilizado um volume de $1 \mathrm{~L}$ de amostra com vazão de aproximadamente $10 \mathrm{~mL} \mathrm{mim}{ }^{-1}$. Após passar todo o volume de amostra, o cartucho foi lavado com $6 \mathrm{~mL}$ de água ácida (destilada e acidificada com $\mathrm{H}_{2} \mathrm{SO}_{4}$ ) a $\mathrm{pH} 3$ para a retirada dos interferentes e seco a vácuo. Posteriormente, os quimioterápicos foram eluídos com $2 \times 2 \mathrm{~mL}$ de metanol mais $2 \mathrm{~mL}$ de metanol com $1 \%$ em volume de ácido fórmico. $\mathrm{O}$ eluato foi levado à secura com $\mathrm{N}_{2}$ e aquecimento em banho com temperatura abaixo de $60^{\circ} \mathrm{C}$ e ressuspendido em $1 \mathrm{~mL}$ de uma solução 10:90 em volume de acetonitrila:água ácida a pH 3. Após foram filtradas em membrana de $0,22 \mu \mathrm{m}$ de porosidade.

As análises foram realizadas em um sistema ACQUITY UPLC - Xevo TQ MS LC/MS-MS, constituído de um auto-injetor modelo Sample Manager; Bomba de UPLC, modelo Binary Solvent Manager; Forno cromatográfico, High-Temp Column Heater, todos da Waters; Coluna analítica Waters C8 $(2,1 \mathrm{~mm} \times 50 \mathrm{~mm} \times 1,7 \mu \mathrm{m})$.

No desenvolvimento do método MRM (Multiple Reaction Monitoring) foram otimizadas a voltagem do capilar e do cone, energia de colisão e temperatura de dessolvatação. Em seguida, deu-se início à otimização da separação cromatográfica e, por fim, do dwell time.

A separação cromatográfica foi realizada em modo gradiente, empregando-se uma vazão de $0,3 \mathrm{~mL} \mathrm{~min}^{-1}$, utilizando-se $\mathrm{ACN}$ e $\mathrm{H}_{2} \mathrm{O}$ com $0,1 \%$ de ácido fórmico como fase móvel. A temperatura do forno foi mantida a $40^{\circ} \mathrm{C}$. Foram monitoradas 24 transições $(\mathrm{m} / \mathrm{z})$, sendo um primeiro íon de quantificação e um segundo de confirmação, para cada um dos analítos de interesse. O sistema ACQUITY UPLC - Xevo TQ MS LC/MS-MS foi operado no modo positivo (ES+), nas seguintes condições: tensão no capilar $3,0 \mathrm{kV}$; voltagem no cone $30 \mathrm{kV}$; temperatura da fonte $150^{\circ} \mathrm{C}$; temperatura de dessolvatação $400^{\circ} \mathrm{C}$; vazão do gás de dessolvatação $800 \mathrm{~L} \mathrm{~h}^{-1}$; vazão do gás de colisão $20 \mathrm{~mL} \mathrm{~min}^{-1}$.

Os padrões analíticos dos fármacos foram adiquiridos da Sigma-Aldrich ${ }^{\circledR}$. As soluções-estoque foram preparadas em ACN:MeOH (50:50) e armazenadas em freezer. As curvas analíticas foram construídas com sete pontos e em triplicata, os coeficientes lineares e angulares foram calculados através da equação da reta obtida graficamente por meio da média das áreas dos cromatogramas em função da concentração nos sete níveis. 
Para o desenvolvimento, a otimização do método e a construção das curvas analíticas foi utilizada água do mar sintética de acordo com a U.S. Environmental Protection Agency (EPA, 2002).

Foram preparados $20 \mathrm{~L}$ de água do mar sintética. Foram dissolvidos os sais de acordo com a Tabela 4, em água deionizada. A solução foi aerada por 24 horas. Tabela 4 - Composição da água do mar sintética.

\begin{tabular}{|c|c|c|}
\hline Composto & Concentração (g/L) & Quantidade p/ $20 \mathrm{~L}$ (g) \\
\hline $\mathrm{NaCl}$ & 21,03 & 420,6 \\
\hline $\mathrm{Na}_{2} \mathrm{SO}_{4}$ & 3,52 & 70,4 \\
\hline $\mathrm{KCl}$ & 0,61 & 12,2 \\
\hline $\mathrm{KBr}$ & 0,088 & 1,76 \\
\hline $\mathrm{Na}_{2} \mathrm{~B}_{4} \mathrm{O}_{7} \cdot 10 \mathrm{H}_{2} \mathrm{O}$ & 0,034 & 0,68 \\
\hline $\mathrm{MgCl}_{2} \cdot 6 \mathrm{H}_{2} \mathrm{O}$ & 9,50 & 190,0 \\
\hline $\mathrm{CaCl}_{2} \cdot 2 \mathrm{H}_{2} \mathrm{O}$ & 1,32 & 26,4 \\
\hline $\mathrm{SrCl}_{2} \cdot 6 \mathrm{H}_{2} \mathrm{O}$ & 0,02 & 0,400 \\
\hline $\mathrm{NaHCO}_{3}$ & 0,17 & 3,40 \\
\hline
\end{tabular}

FONTE: EPA, 2002, p. 34.

\subsection{Análise de Carbono Orgânico Dissolvido}

Para a determinação de Carbono Orgânico Dissolvido (COD), as amostras foram filtradas em membrana de 0,45 $\mu \mathrm{m}$ de porosidade e posteriormente analisadas em um analisador TOC Sievers InnovOx da marca $\mathrm{GE}^{\circledR}$.

\subsection{Determinação da salinidade}

Para se determinar a salinidade de cada ponto de coleta, uma determinada massa de amostra foi adicionada à um béquer tarado. O béquer foi levado quase à secura em banho-maria e, em seguida, à estufa a $140^{\circ} \mathrm{C}$ por aproximadamente 1 hora. Após esfriar em dessecador, o béquer com os sais secos foi pesado à massa constante. 


\subsection{Concentração de saturação de oxigênio dissolvido}

Utilizando-se a salinidade e a temperatura de cada ponto de coleta, fez-se o cálculo da concentração de saturação de oxigênio dissolvido. De acordo com Benson e Krause (1984), a concentração de saturação de oxigênio dissolvido pode ser calculada pela Equação 1, onde $C_{s}$ é a concentração de saturação de oxigênio dissolvido $\left[\mu \mathrm{mol} \mathrm{kg}{ }^{-1}\right]$; $T$ é a temperatura $[\mathrm{K}]$; S é a salinidade [\%o]. As constantes são: $A=-1,352996 \times 10^{2} ; \quad B=1,572288 \times 10^{5} ; \quad C=-6,637149 \times 10^{7} ; \quad D=1,243678 \times$ $10^{10} ; \quad E=-8,621061 \times 10^{11} ; \quad F=2,0573 \times 10^{-2} ; \quad G=-1,2142 \times 10^{1} ;$ e $H=2,3631 \times$ $10^{3}$

$$
\ln C_{S}=A+\frac{B}{T}+\frac{C}{T^{2}}+\frac{D}{T^{3}}+\frac{E}{T^{4}}-S \times\left(F+\frac{G}{T}+\frac{H}{T^{2}}\right)
$$

\subsection{Análise dos Resultados}

A distribuição espaço-temporal foi determinada por Análise de Componentes Principais (PCA), utilizando o software PAST ${ }^{\circledR}($ HAMMER; HARPER; RYAN, 2001). 


\section{RESULTADOS E DISCUSSÃO}

\subsection{Parâmetros determinados in situ}

A Tabela 5 apresenta os resultados das análises realizadas nos pontos de coleta de ambas as campanhas.

Tabela 5 - Resultado das análises realizadas in situ.

\begin{tabular}{|c|c|c|c|c|c|c|c|c|}
\hline \multirow[b]{2}{*}{ AMOSTRA } & \multicolumn{4}{|c|}{2014} & \multicolumn{4}{|c|}{2015} \\
\hline & $\begin{array}{c}\mathrm{T} \\
\left({ }^{\circ} \mathrm{C}\right) \\
\end{array}$ & $\begin{array}{c}\text { OD } \\
\left(\mathrm{mg} \mathrm{L}^{-1}\right)\end{array}$ & $\mathrm{pH}$ & $\begin{array}{l}\text { ORP* } \\
(\mathrm{mV})\end{array}$ & $\begin{array}{c}\mathrm{T} \\
\left({ }^{\circ} \mathrm{C}\right) \\
\end{array}$ & $\begin{array}{c}\text { OD } \\
\left(\mathrm{mg} \mathrm{L}^{-1}\right)\end{array}$ & $\mathrm{pH}$ & $\begin{array}{l}\text { ORP* } \\
(\mathrm{mV})\end{array}$ \\
\hline L1 & 19,5 & 5,85 & 6,46 & 90,0 & 25,7 & 4,52 & 7,33 & 77,8 \\
\hline L2 & 21,0 & 7,13 & 6,41 & 283,8 & 23,9 & 6,21 & 7,11 & 162,3 \\
\hline G1 & 22,5 & 6,10 & 6,29 & 112,4 & 25,6 & 3,90 & 6,94 & $-20,6$ \\
\hline G2 & 26,0 & 5,94 & 7,76 & 50,4 & 30,7 & 4,34 & 7,94 & $-35,8$ \\
\hline A1 & 22,4 & 0,93 & 6,34 & $-246,2$ & 26,9 & 0,27 & 7,16 & $-113,6$ \\
\hline A2 & 24,4 & 6,02 & 7,88 & 28,4 & 30,4 & 5,16 & 8,24 & $-14,7$ \\
\hline 11 & 24,3 & 1,27 & 7,38 & 92,2 & 31,4 & 2,5 & 7,94 & $-97,4$ \\
\hline 12 & 26,1 & 4,06 & 7,80 & 76,7 & 32,4 & 5,95 & 8,02 & $-9,4$ \\
\hline B1 & 23,4 & 6,14 & 7,98 & 43,1 & 29 & 5,19 & 8,42 & $-14,0$ \\
\hline B2 & 23,8 & 6,23 & 8,03 & 49,1 & 28,9 & 3,72 & 8,35 & $-16,2$ \\
\hline B3 & 23,9 & 6,34 & 8,03 & 51,7 & 28,7 & 5,42 & 8,47 & $-14,5$ \\
\hline B4 & 23,8 & 6,41 & 8,06 & 56,3 & 29 & 5,69 & 8,49 & $-12,2$ \\
\hline B5 & 22,5 & 6,76 & 8,05 & 50,3 & 28,8 & 5,76 & 8,49 & $-13,4$ \\
\hline B6 & 23,7 & 4,58 & 7,84 & 68,5 & 29,2 & 5,02 & 8,32 & $-3,6$ \\
\hline B7 & 23,8 & 5,59 & 7,98 & 68,2 & 29,4 & 4,36 & 8,42 & $-20,8$ \\
\hline B8 & 24,0 & 5,64 & 8,10 & 66,2 & 29,7 & 3,48 & 8,38 & $-18,3$ \\
\hline
\end{tabular}

${ }^{*}$ Potencial redox

Os resultados de $\mathrm{pH}$ obtidos durante a primeira e segunda campanha variaram de 6,29 a 8,28 nos rios e de 7,84 a 8,49 na baía. A concentração de íons $\mathrm{H}^{+}$ afeta de maneira significativa a solubilidade de diversos compostos, tais como metais adsorvidos em sedimentos e a toxicidade dos compostos. Segundo a Resolução CONAMA 357/05, os valores de pH para águas salobras e salinas devem estar dentro do intervalo de 6,5 a 8,5. Portanto, os valores obtidos enquadram-se dentro dos limites estabelecidos com exceção dos pontos A1, G1, L1 e L2 da campanha de 2014 que apresentaram pH abaixo de 6,5. 
Analisando-se a Figura 11, onde é apresentada a diferença entre o pH medido e 7,5 (que é a média do intervalo permitido pela resolução CONAMA 357/05), nota-se que, de maneira geral, a baía apresentou $\mathrm{pH}$ mais alcalino e os rios levemente ácidos, como era de se esperar devido à maior quantidade de sais dissolvidos na baía. Nota-se também que a baía sofre muito pouca variação de $\mathrm{pH}$ quando comparada aos rios.

Figura $11-(\mathrm{pH}-7,5)$ em ambas as campanhas de amostragem ( $\square$ inverno e $\square$ verão).

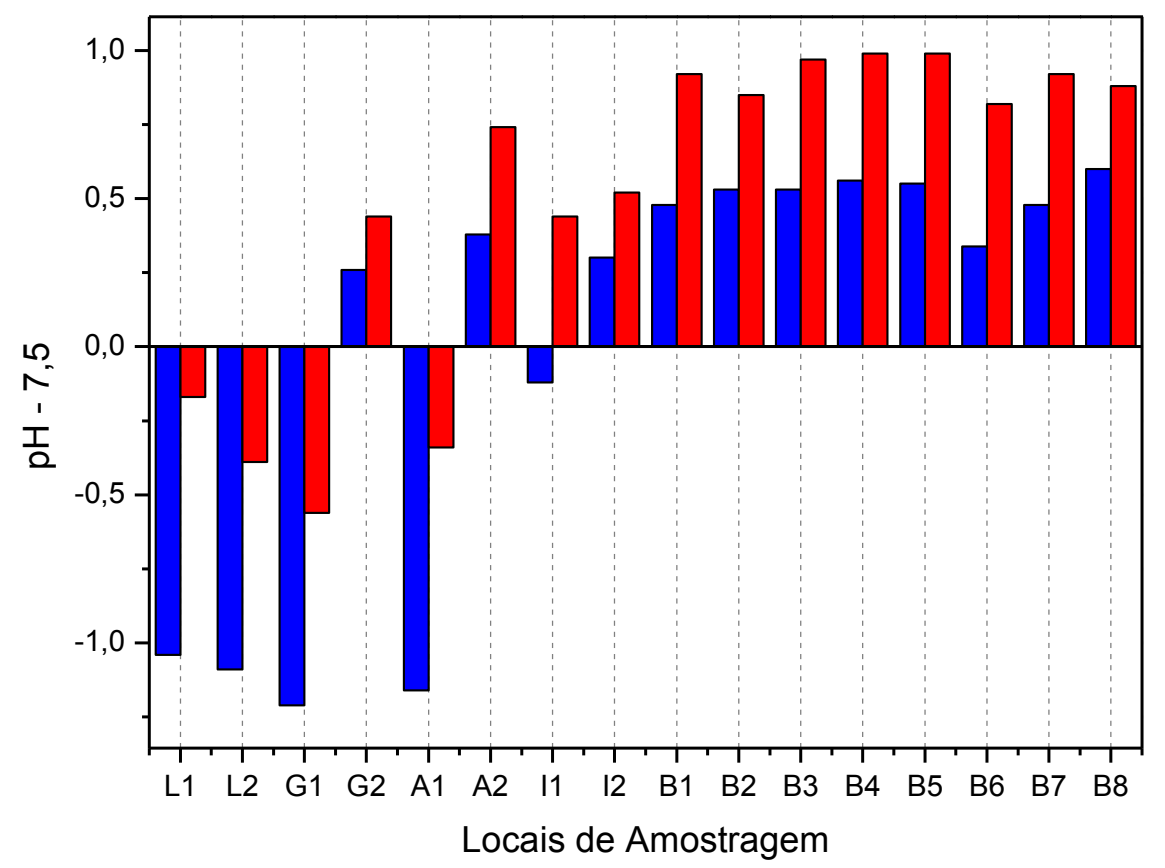

No inverno, os valores de $\mathrm{pH}$ se apresentaram mais baixos que no verão, ou seja, no verão as águas estavam mais alcalinas que no inverno. Como o verão é a época chuvosa, isso provavelmente se deve à acidez da chuva. Segundo Kaushal et al. (2013), chuvas ácidas dissolvem rochas e pavimentos ricos em metais alcalinos e alcalinos terrosos, levando-os para os corpos d'água e acarretando a sua alcalinização.

A temperatura dos corpos d'água na primeira campanha variou de 19,5 a $26,7^{\circ} \mathrm{C}$ nos rios e 22,5 a $24,0^{\circ} \mathrm{C}$ no mar. Na segunda campanha variou de 23,9 a $33,1^{\circ} \mathrm{C}$ nos rios e 28,7 a $29,7^{\circ} \mathrm{C}$ no mar. A temperatura exerce influência em outros parâmetros físico-químicos tal como condutividade e concentração de oxigênio dissolvido. Como a primeira campanha de amostragem foi realizada no final do período seco correspondente ao final do inverno e a segunda campanha foi realizada no final 
do período chuvoso correspondente ao final do verão, os resultados obtidos apresentaram coerência sazonal.

Os valores de potencial de oxirredução na primeira campanha foram positivos, salvo o ponto A1 com - 246,2 $\mathrm{mV}$ e na segunda campanha foram negativos, salvos os pontos L1 com 77,8 mV e L2 com 162,3 mV. Na Figura 12 pode-se notar que no inverno os corpos d'água apresentaram-se predominantemente oxidantes e no verão, redutores. Valores baixos de potencial de oxirredução estão provavelmente relacionados com baixas concentrações de oxigênio dissolvido, situação na qual os processos redutivos são dominantes, tais como a respiração anaeróbia de bactérias, resultado de uma provável contaminação por esgoto doméstico.

Figura 12 - ORP em ambas as campanhas de amostragem ( $\square$ inverno e $\square$ verão).

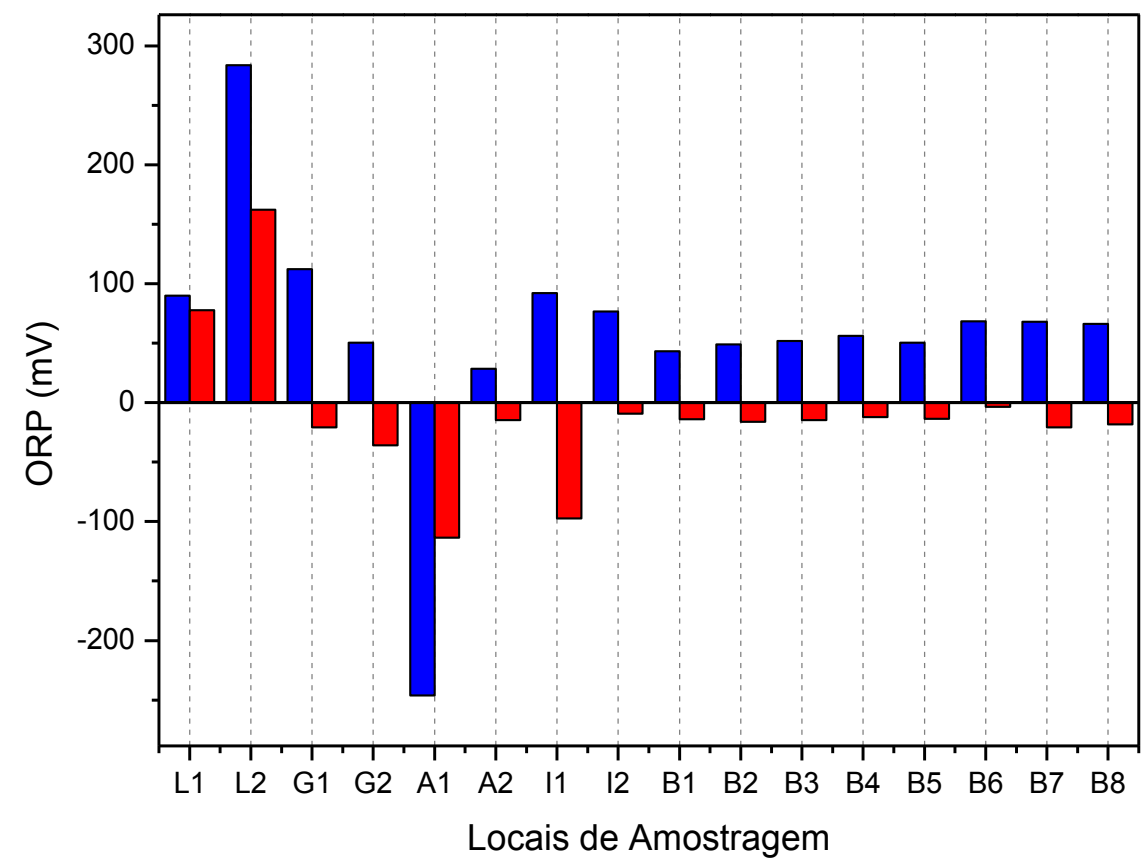

Os resultados obtidos de oxigênio dissolvido durante a primeira campanha de amostragem foram, no geral, maiores do que na segunda campanha. A Tabela 6, mostra os valores de OD mínimos para diferentes classes de águas, segundo a Resolução CONAMA 357/05. 
Tabela 6 - Classificação das águas segundo a Resolução CONAMA 357/05.

\begin{tabular}{ccc}
\hline Águas salinas & $\begin{array}{c}\text { Águas } \\
\text { salobras }\end{array}$ & OD $\left(\mathbf{m g ~ L}^{\mathbf{- 1}}\right)$ \\
\hline Classe I & - & $\geq 6,0$ \\
\hline Classe II & Classe I & $\geq 5,0$ \\
\hline Classe III & Classe II & $\geq 4,0$ \\
\hline & Classe III & $\geq 2,0$ \\
\cline { 2 - 3 }
\end{tabular}

Uma concentração de oxigênio dissolvido adequada é indispensável para a manutenção da vida aquática. O despejo de efluentes domésticos ou industriais que aumentem a concentração de matéria orgânica nos corpos d'água receptores contribui para o processo de eutrofização, pois causam aumento na atividade biológica e consequentemente maior consumo de oxigênio.

De acordo com a Tabela 7, os pontos G2 e L2 da primeira campanha se enquadram como águas salinas. Nota-se que na primeira campanha (Tabela 5), dos pontos de água salobra, A2, L1 e G1 apresentaram OD superior a $5,0 \mathrm{mg} \mathrm{L}^{-1}$, ou seja, se enquadram como classe I neste parâmetro. O ponto I2 se enquadra como classe II e os pontos I1 e A1 não se enquadram sequer como classe III, pois apresentaram OD inferior a $2 \mathrm{mg} \mathrm{L}^{-1}$. Dentre os pontos de água salina, L2, B1, B2, B3, B4 e B5 se enquadram como classe I. Os pontos B7 e B8 se enquadram como classe II e o ponto B6 se enquadra como classe III.

$\mathrm{Na}$ segunda campanha de amostragem somente os pontos B3 e B4 se enquadram como águas salinas (Tabela 7). Os pontos L2, A2, I2, B1, B5 e B6 apresentaram OD superior a $5,0 \mathrm{mg} \mathrm{L}^{-1}$, ou seja, classe I neste parâmetro. Os pontos L1, G2 e B7 se enquadram como classe II. Os pontos G1, I1 B2 e B8 se enquadram como classe III. O ponto A1 não se enquadra sequer como classe III, por possuir OD inferior a $2 \mathrm{mg} \mathrm{L}^{-1}$. Os pontos de água salina baía, B3 e B4 se enquadram como classe II.

Talvez mais importante que o OD seja a diferença entre ele a concentração de saturação de oxigênio (Cs). Para calculá-la, determinou-se a salinidade de cada ponto de amostragem e, de posse dos valores de temperatura, usou-se a Equação 1. O resultado é mostrado na Tabela 7. Nota-se que, com exceção do 
ponto B4 na primeira campanha, todos os pontos de coleta estavam abaixo da concentração de saturação de oxigênio dissolvido e alguns pontos se destacam por estar muito abaixo, tal como o ponto $\mathrm{A} 1$ e $\mathrm{I1}$ da primeira campanha e os pontos $\mathrm{G} 1$, A1 , I1, B2 e B8 da segunda campanha.

Tabela 7 - Concentração de saturação de oxigênio dissolvido de cada ponto de amostragem.

\begin{tabular}{c|ccc|ccc}
\cline { 2 - 7 } & \multicolumn{3}{|c|}{$\mathbf{2 0 1 4}$} & \multicolumn{3}{c}{$\mathbf{2 0 1 5}$} \\
\hline AMOSTRA & \%o sal & $\begin{array}{c}\text { Cs } \\
\text { (ppm) }\end{array}$ & $\begin{array}{c}\text { OD } \\
\text { (ppm) }\end{array}$ & \%o sal & $\begin{array}{c}\text { Cs } \\
\text { (ppm) }\end{array}$ & $\begin{array}{c}\text { OD } \\
\text { (ppm) }\end{array}$ \\
\hline L1 & 1,58 & 8,73 & 5,85 & 1,29 & 8,07 & 4,52 \\
L2 & 41,4 & 6,55 & 7,13 & 22,3 & 6,84 & 6,21 \\
G1 & 13,0 & 7,67 & 6,10 & 4,79 & 7,66 & 3,90 \\
G2 & 32,7 & 6,38 & 5,94 & 26,9 & 6,14 & 4,34 \\
A1 & 1,39 & 8,28 & 0,93 & 1,93 & 7,62 & 0,27 \\
A2 & 25,8 & 6,84 & 6,02 & 10,9 & 6,80 & 5,16 \\
I1 & 1,91 & 7,98 & 1,27 & 1,19 & 7,10 & 2,50 \\
I2 & 33,1 & 6,35 & 4,06 & 21,9 & 6,16 & 5,95 \\
B1 & 37,6 & 6,45 & 6,14 & 28,3 & 6,25 & 5,19 \\
B2 & 33,6 & 6,57 & 6,23 & 28,7 & 6,24 & 3,72 \\
B3 & 46,8 & 6,03 & 6,34 & 32,4 & 6,12 & 5,42 \\
B4 & 44,1 & 6,14 & 6,41 & 33,6 & 6,04 & 5,69 \\
B5 & 20,3 & 7,32 & 6,76 & 21,2 & 6,55 & 5,76 \\
B6 & 27,3 & 6,85 & 4,58 & 24,4 & 6,38 & 5,02 \\
B7 & 37,8 & 6,40 & 5,59 & 22,7 & 6,43 & 4,36 \\
B8 & 33,0 & 6,57 & 5,64 & 25,0 & 6,31 & 3,48 \\
\hline
\end{tabular}

Analisando-se a Figura 13, pode-se notar a diferença de salinidade entre a campanha de amostragem do inverno (seco) e a do verão (chuvoso). Com a menor precipitação no inverno os sais dissolvidos nos corpos d'água estavam mais concentrados que no período chuvoso, correspondente ao verão.

Segundo a resolução CONAMA 357/05 águas salinas são aquelas com mais de $30 \%$ de salinidade, salobras entre 0,5 e $30 \%$ e abaixo de $0,5 \%$ são classificadas como água doce. 
Figura 13 - Salinidade em ambas as campanhas de amostragem ( $\square$ inverno e $\square$ verão).

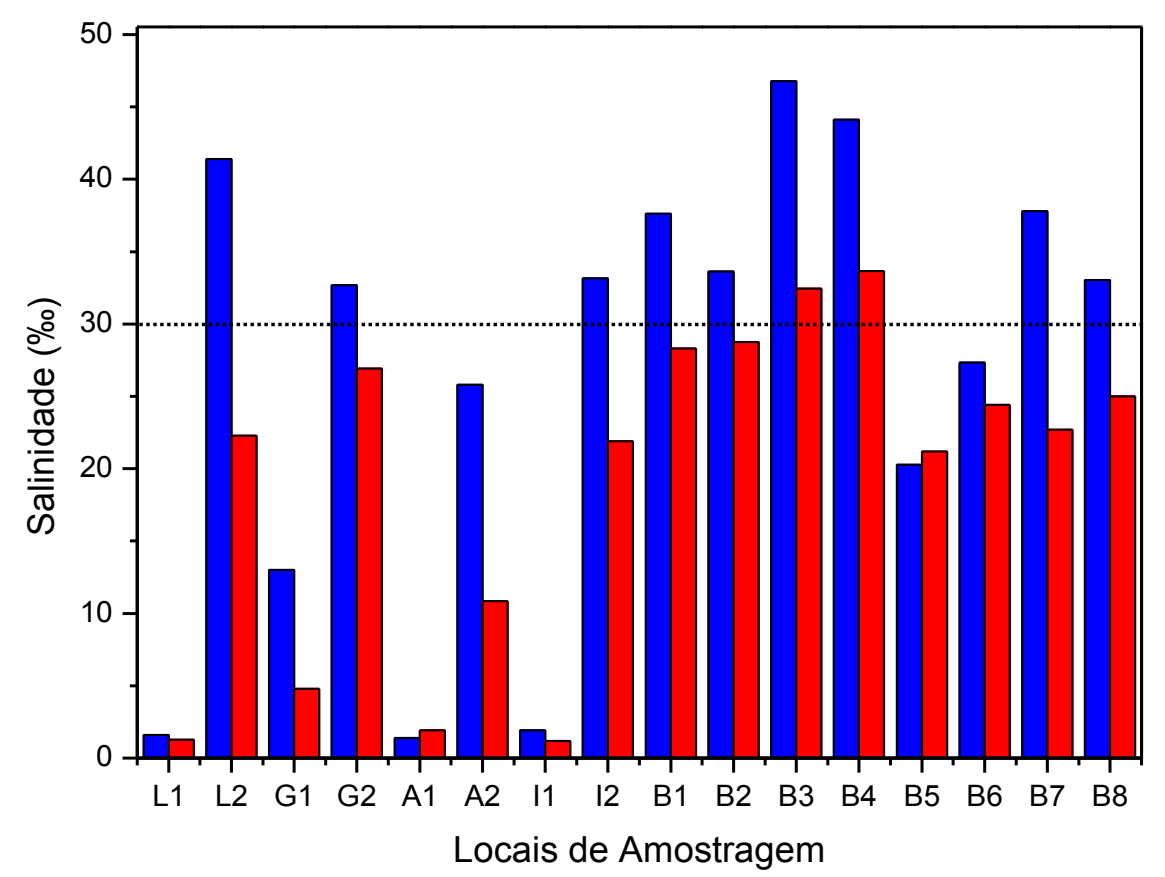

Nota-se que nenhum dos locais de amostragem pode ser classificado como água doce; mesmo os rios apresentaram águas salobras e como era de se esperar a salinidade aumenta conforme o rio se aproxima do mar, tornando-se salinos em sua foz devido à penetração do mar nos rios. No verão a água da baía está majoritariamente salobra.

A Figura 14 apresenta, então, o "desvio" em relação à concentração de saturação de oxigênio em cada ponto de amostragem, em ambas as coletas. De maneira geral, independentemente da estação do ano, os pontos de amostragem apresentaram depleção do oxigênio dissolvido, e este fato é ainda pior no verão. Os pontos L2, B3 e B4 do inverno de 2014 apresentaram valores de OD ligeiramente acima da Cs, talvez indicando uma possível eutrofização (ANA, 2016). 
Figura 14 - (OD - Cs) em ambas as campanhas de amostragem ( $\square$ inverno e $\square$ verão).

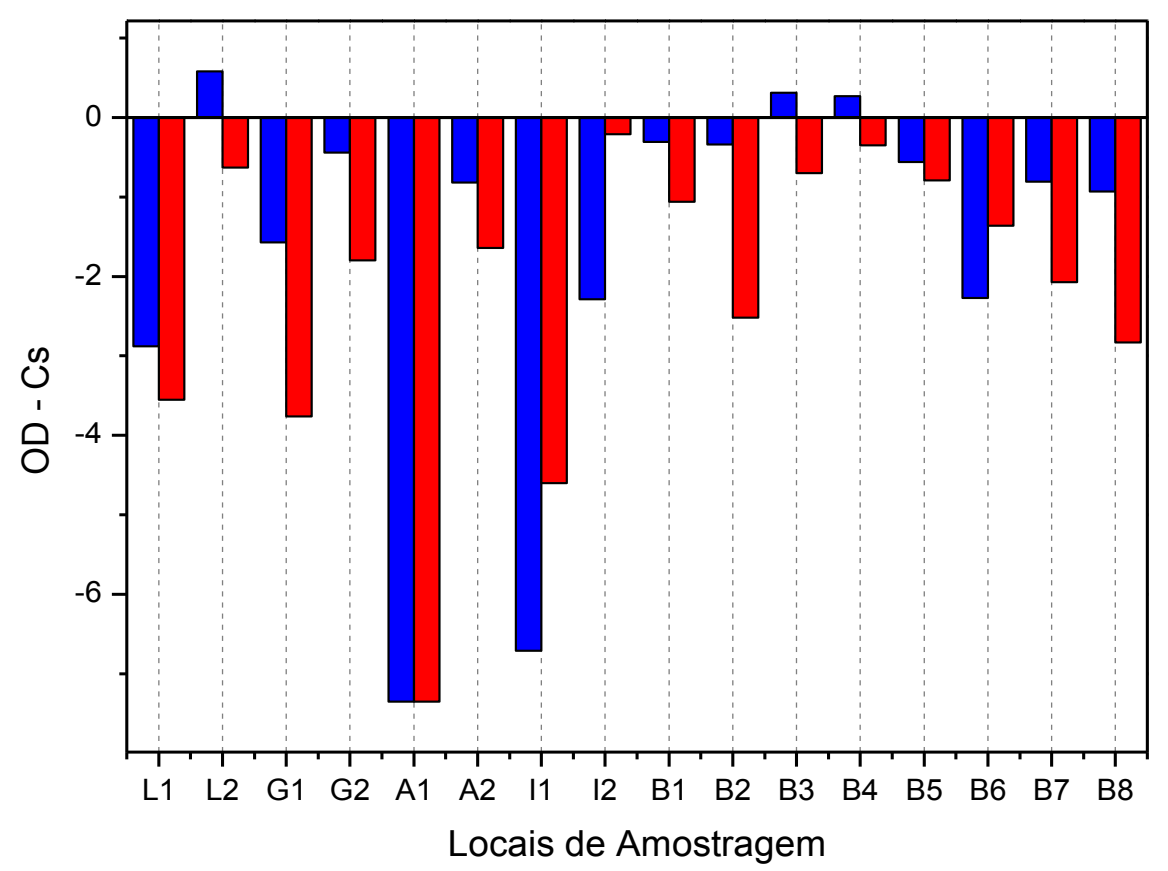

A depleção de oxigênio é maior nos rios do que na baía e o rio Acaraú é o mais impactado, independentemente da época do ano. De uma maneira geral os pontos da baía que estão mais próximos à praia apresentam maior depleção de oxigênio quando comparados aos pontos da saída da baía. Dos pontos na baía, o ponto B8, localizado próximo à foz do rio Acaraú, apresentou menor teor de OD, no verão de 2015 e o ponto B6 o menor no inverno de 2014.

Comparando-se a Figura 14 com a Figura 12, nota-se que os locais de amostragem com maior depleção de oxigênio apresentaram menor potencial de oxirredução, atestando um meio redutor, enquanto que nos pontos onde OD estava mais próximo de Cs, ou até mesmo maior, o meio estava oxidante, como era de se esperar.

\subsection{Análise de carbono orgânico dissolvido}

A Tabela 8 apresenta os dados obtidos na determinação de carbono orgânico dissolvido. 
Tabela 8 - Concentração carbono orgânico dissolvido em cada ponto de amostragem.

\begin{tabular}{cc|c} 
& \multicolumn{2}{c}{ COD $\left(\mathbf{m g ~ L}^{\mathbf{- 1}}\right)$} \\
\cline { 2 - 3 } AMOSTRA & $\mathbf{2 0 1 4}$ & $\mathbf{2 0 1 5}$ \\
\hline L1 & 1,60 & 2,35 \\
L2 & 2,62 & 3,22 \\
G1 & 1,90 & 2,58 \\
G2 & 4,19 & 4,19 \\
A1 & 6,73 & 7,19 \\
A2 & 8,11 & 2,49 \\
I1 & 2,72 & 3,26 \\
I2 & 2,31 & 1,99 \\
B1 & 4,63 & 1,68 \\
B2 & 1,52 & 1,27 \\
B3 & 2,51 & 3,34 \\
B4 & 1,74 & 1,02 \\
B5 & 1,36 & 0,96 \\
B6 & 1,69 & 0,61 \\
B7 & 1,17 & 2,48 \\
B8 & 4,25 & 0,99 \\
\hline
\end{tabular}

A Figura 15 apresenta uma comparação entre o inverno e o verão, nota-se que no inverno e no verão a concentração de COD se mantém praticamente constante, considerando maior precipitação no verão e então diluição nos corpos d'água, o aumento da densidade demográfica neste período compensa esse fenômeno.

Comparando-se a Figura 15 com a 14, pode-se notar que quanto maior a concentração de $C O D$, menor é a concentração de $O D$, isso se deve provavelmente ao aumento do consumo de oxigênio ocasionado pelo aumento na atividade bacteriana pelo excesso de nutrientes no corpo d'água. 
Figura 15 - Concentração de carbono orgânico em ambas as campanhas

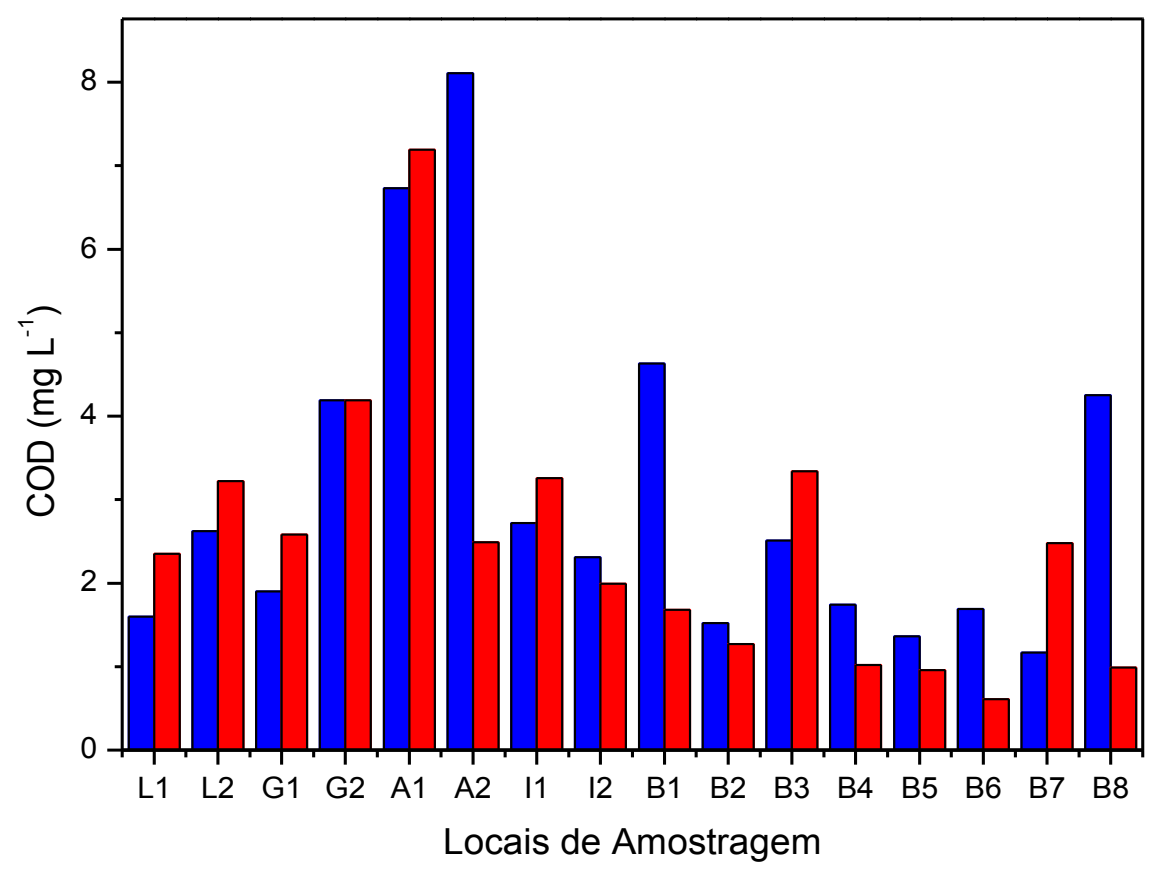

\subsection{Análise dos antimicrobianos}

Durante o desenvolvimento do método cromatográfico, buscou-se uma análise cromatográfica capaz de separar, identificar e quantificar, no menor tempo possível, os antimicrobianos das classes das sulfonamidas e das fluoroquinolonas na mesma análise em uma matriz real. A Tabela 9 apresenta o gradiente de eluição do método e a Figura 16 apresenta o cromatograma de íons totais (TIC) para as 7 SAs, as 4 FQs e a trimetoprima.

Tabela 9 - Gradiente de eluição utilizado no método cromatográfico multirresíduo desenvolvido (vazão $=0,300 \mathrm{~mL} \mathrm{~min}^{-1}$ ).

\begin{tabular}{ccc}
\hline $\begin{array}{c}\text { Tempo } \\
(\mathbf{m i n})\end{array}$ & $\% \mathbf{A}\left(\mathbf{H}_{\mathbf{2}} \mathbf{O}\right)$ & $\% \mathrm{~B}(\mathbf{A C N})$ \\
\hline 0,00 & 95 & 5 \\
3,00 & 85 & 15 \\
4,50 & 60 & 40 \\
4,60 & 35 & 65 \\
5,10 & 35 & 65 \\
5,50 & 95 & 50 \\
7,00 & 95 & 50 \\
\hline
\end{tabular}


Figura 16 - Exemplo de cromatograma de íons totais obtido para uma amostra da água do mar sintética, fortificada com fluoroquinolonas e sulfonamidas $\left(500 \mathrm{ng} \mathrm{L}^{-1}\right)$.

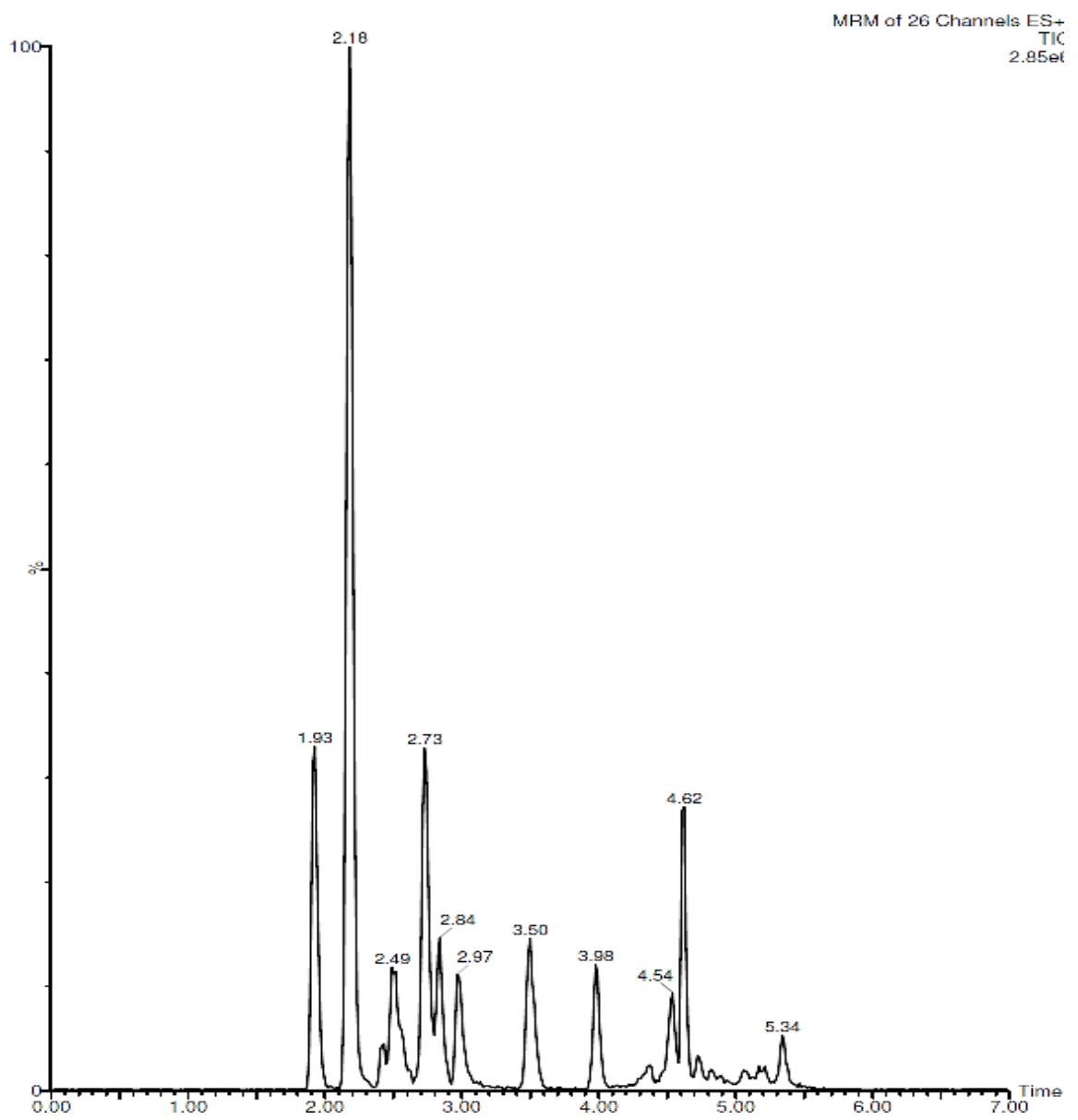

As sulfonamidas apresentam padrão de fragmentação típico com os íons de quantificação $\mathrm{m} / \mathrm{z}$ 156, 92 e 186. Os íons que se mostraram mais intensos foram escolhidos como íons de quantificação e os segundos mais intensos como íons de determinação. As energias de colisão foram otimizadas individualmente para cada composto. Esta otimização dos íons de determinação e quantificação e os demais parâmetros foram selecionados por meio do software Masslynx v4.1 Intellistarts $^{\mathrm{TM}}$ (Tabela 10). 
Tabela 10 - Parâmetros de quantificação e confirmação no modo MRM (Multiple Reaction Monitoring). Tempo de aquisição (dwell time) =0,030 s.

\begin{tabular}{|c|c|c|c|c|c|}
\hline Composto & $\underset{(\min )}{t_{R}}$ & $\begin{array}{c}\text { Composto } \\
\text { Primário } \\
(\mathrm{m} / \mathrm{z})\end{array}$ & $\begin{array}{c}\text { Fragmento } \\
(\mathrm{m} / \mathrm{z})\end{array}$ & $\begin{array}{c}\text { Energia do } \\
\text { Cone (V) }\end{array}$ & $\begin{array}{l}\text { Energia de } \\
\text { colisão (V) }\end{array}$ \\
\hline Sulfametoxazol* & 3,98 & 254,01 & 107,97 & 14 & 22 \\
\hline Sulfametoxazol & 3,98 & 254,01 & 155,98 & 14 & 16 \\
\hline Sulfatiazol* & 1,93 & 256,01 & 92,00 & 14 & 24 \\
\hline Sulfatiazol & 1,93 & 256,01 & 155,97 & 14 & 14 \\
\hline Sulfamerazina* & 2,16 & 265,08 & 92,00 & 16 & 30 \\
\hline Sulfamerazina & 2,16 & 265,08 & 155,92 & 16 & 16 \\
\hline Sulfametizol* & 2,82 & 271,08 & 92,00 & 12 & 26 \\
\hline Sulfametizol & 2,84 & 271,08 & 155,93 & 12 & 14 \\
\hline Sulmetazina* & 2,73 & 279,07 & 92,00 & 16 & 28 \\
\hline Sulmetazina & 2,73 & 279,07 & 186,01 & 16 & 18 \\
\hline Sulfacloropiridiazina* & 3,50 & 285,03 & 92,00 & 14 & 28 \\
\hline Sulfacloropiridiazina & 3,49 & 285,03 & 155,98 & 14 & 14 \\
\hline Trimetoprima* & 2,18 & 291,14 & 123,02 & 24 & 24 \\
\hline Trimetroprima & 2,18 & 291,14 & 230,02 & 24 & 24 \\
\hline Sulfaquinoxalina* & 4,61 & 301,08 & 92,00 & 16 & 28 \\
\hline Sulfaquinoxalina & 4,61 & 301,08 & 155,97 & 16 & 16 \\
\hline Norfloxacina* & 2,42 & 320,16 & 276,00 & 18 & 23 \\
\hline Norfloxacina & 2,42 & 320,16 & 302,00 & 18 & 29 \\
\hline Ciprofloxacina* & 2,56 & 332,16 & 231,05 & 18 & 34 \\
\hline Ciprofloxacina & 2,57 & 332,16 & 288,00 & 18 & 25 \\
\hline Pefloxacina* & 2,50 & 334,16 & 233,06 & 18 & 26 \\
\hline Pefloxacina & 2,50 & 334,16 & 290,00 & 18 & 25 \\
\hline Enrofloxacina* & 2,98 & 360,16 & 245,10 & 18 & 28 \\
\hline Enrofloxacina & 2,98 & 360,16 & 286,04 & 18 & 32 \\
\hline
\end{tabular}

* Transições de quantificação.

Para se determinar o limite de quantificação $\left(\operatorname{LOQ}_{(\text {estimado) }}\right)$, fez-se uma análise de uma amostra de concentração conhecida e de acordo com a relação Sinal/Ruído estimou-se a concentração onde iria se obter a relação Sinal/Ruido igual a 10. Esta concentração é o $L O Q_{\text {(estimado). }}$

As curvas analíticas foram construídas nas concentrações de $L O Q_{(\text {(estimado) }}, 50$, $150,250,350,450$ e $550 \mathrm{ng} \mathrm{L}^{-1}$, para as sulfonamidas e trimetoprima e nas concentrações de $\mathrm{LOQ}_{\text {(estimado), }} 100,200,300,400,500$ e $600 \mathrm{ng} \mathrm{L}^{-1}$, para as fluoroquinolonas. 
Na Tabela 11 são apresentados as equações de reta e os coeficientes de determinação $\left(R^{2}\right)$ para as SAs e FQs.

Tabela 11 - Linearidade para a detecção de sulfonamidas e fluoroquinolonas.

\begin{tabular}{|c|c|c|}
\hline \multirow{2}{*}{ Composto } & \multicolumn{2}{|c|}{ Linearidade } \\
\hline & Equação & $\mathbf{R}^{2}$ \\
\hline Sulfametoxazol & $y=12,624 x+71,926$ & 0,994 \\
\hline Sulfatiazol & $y=46,352 x+526,89$ & 0,996 \\
\hline Sulfamerazina & $y=57,533 x+1032,1$ & 0,993 \\
\hline Sulfametizol & $y=22,466 x-110,3$ & 0,991 \\
\hline Sulfametazina & $y=52,973 x+753,67$ & 0,992 \\
\hline Sulfacloropiridiazina & $y=26,56 x-38,458$ & 0,995 \\
\hline Sulfaquinoxalina & $y=40,978 x-305,27$ & 0,994 \\
\hline Trimetoprina & $y=88,305 x+436,52$ & 0,994 \\
\hline Norfloxacina & $y=5,7202 x+170,56$ & 0,972 \\
\hline Ciprofloxacina & $y=5,0813 x-68,375$ & 0,955 \\
\hline Perfloxacina & $y=26,253 x+329,22$ & 0,987 \\
\hline Enrofloxacina & $y=37,129 x+309,16$ & 0,991 \\
\hline
\end{tabular}

Para a determinação do limite de quantificação (LOQ) e limite de detecção (LOD), seguiu-se a Resolução 899 da ANVISA que estipula que o limite de detecção pode ser calculado pelas Equações 2 e 3, nas quais $\mathrm{DP}_{\mathrm{a}}$ é o desvio-padrão do intercepto com o eixo y de, no mínimo, três curvas de calibração construídas contendo concentrações próximas ao suposto limite de quantificação e IC é a inclinação da curva de calibração.

$$
\begin{gathered}
L O D=\frac{D P_{a} \times 3}{I C} \\
L O Q=\frac{D P_{a} \times 10}{I C}
\end{gathered}
$$

Na Tabela 12 são apresentados os valores de LOQ e LOD para cada composto quantificado. A Tabela 13 apresenta os valores das concentrações dos antimicrobianos, em ng L ${ }^{-1}$, em cada ponto de coleta. 
Tabela 12 - LOD e LOQ do método utilizado.

\begin{tabular}{lcc}
\hline Antimicrobiano & LOD(ng/L) & LOQ(ng/L) \\
\hline Sulfametoxazol & 3,76 & 12,54 \\
Sulfatiazol & 6,67 & 22,23 \\
Sulfamerazina & 4,13 & 13,76 \\
Sulfametizol & 14,91 & 49,69 \\
Sulfametazina & 6,13 & 20,42 \\
Sulfacloropiridazina & 14,19 & 47,31 \\
Sulfaquinoxalina & 7,05 & 23,49 \\
Trimetoprina & 4,06 & 13,55 \\
Norfloxacina & 27,14 & 90,46 \\
Ciprofloxacina & 74,67 & 248,89 \\
Perfloxacina & 16,65 & 55,49 \\
Enrofloxacina & 20,99 & 69,97 \\
\hline
\end{tabular}


Tabela 13 - Resultado da determinação de antimicrobianos SAs e FQs nos pontos de coleta $\left(\mathrm{ng} \mathrm{L}^{-1}\right) .{ }^{\mathrm{D}}<\mathrm{LOD} ;{ }^{\mathrm{Q}}<\mathrm{LOQ}$

\begin{tabular}{|c|c|c|c|c|c|c|c|c|c|c|c|c|c|}
\hline ANO & AMOSTRA & SMX & STZ & SMR & SMZ & SMT & SCP & SQX & TMP & NOR & CIP & PEF & ENR \\
\hline \multirow{18}{*}{2014} & L1 & D & D & D & D & D & D & D & D & D & D & D & D \\
\hline & L2 & D & D & D & D & D & D & D & D & D & D & D & D \\
\hline & L3 & D & D & $\mathrm{D}$ & $\mathrm{D}$ & $\mathrm{D}$ & $D$ & $Q$ & D & $\mathrm{D}$ & $\mathrm{D}$ & D & $\mathrm{D}$ \\
\hline & G1 & D & D & $D$ & $D$ & $D$ & D & $D$ & $D$ & $D$ & $D$ & D & $D$ \\
\hline & G2 & D & D & D & $\mathrm{D}$ & D & D & $\mathrm{D}$ & D & $D$ & $D$ & D & $D$ \\
\hline & G3 & D & D & D & D & D & D & Q & D & D & D & D & D \\
\hline & A1 & $Q$ & D & $\mathrm{D}$ & $\mathrm{D}$ & $\mathrm{D}$ & D & $\mathrm{D}$ & D & $\mathrm{D}$ & $\mathrm{D}$ & D & $\mathrm{D}$ \\
\hline & A2 & $\mathrm{D}$ & D & $\mathrm{D}$ & $\mathrm{D}$ & $\mathrm{D}$ & D & $D$ & D & $\mathrm{D}$ & $\mathrm{D}$ & D & $\mathrm{D}$ \\
\hline & 11 & D & D & $\mathrm{D}$ & $\mathrm{D}$ & $\mathrm{D}$ & D & $\mathrm{D}$ & D & $\mathrm{D}$ & $D$ & D & $\mathrm{D}$ \\
\hline & 12 & $Q$ & D & $\mathrm{D}$ & $\mathrm{D}$ & $\mathrm{D}$ & D & $\mathrm{D}$ & D & $\mathrm{D}$ & $\mathrm{D}$ & D & $\mathrm{D}$ \\
\hline & B1 & $D$ & D & D & $\mathrm{D}$ & D & D & $\mathrm{D}$ & D & $D$ & $D$ & D & $D$ \\
\hline & B2 & D & D & $\mathrm{D}$ & $D$ & $\mathrm{D}$ & D & $Q$ & D & $D$ & $\mathrm{D}$ & D & $D$ \\
\hline & B3 & D & D & $\mathrm{D}$ & $\mathrm{D}$ & $\mathrm{D}$ & D & $\mathrm{D}$ & D & $\mathrm{D}$ & $\mathrm{D}$ & D & $\mathrm{D}$ \\
\hline & B4 & D & D & $\mathrm{D}$ & $\mathrm{D}$ & $\mathrm{D}$ & D & $D$ & D & D & $\mathrm{D}$ & D & $\mathrm{D}$ \\
\hline & B5 & D & D & $\mathrm{D}$ & $D$ & $D$ & D & $D$ & D & 149,72 & $D$ & D & $D$ \\
\hline & B6 & D & D & $D$ & $D$ & $D$ & D & $D$ & D & Q & $D$ & D & $\mathrm{D}$ \\
\hline & B7 & D & D & D & $D$ & D & D & $\mathrm{D}$ & D & $Q$ & D & D & $D$ \\
\hline & B8 & D & D & D & $D$ & D & D & $D$ & D & Q & $D$ & D & $\mathrm{D}$ \\
\hline \multirow{18}{*}{2015} & $\overline{L 1}$ & $\bar{D}$ & $\bar{D}$ & $\mathrm{D}$ & $\mathrm{D}$ & $\mathrm{D}$ & $\bar{D}$ & $Q$ & $\bar{D}$ & $D$ & $\mathrm{D}$ & $\bar{D}$ & $\mathrm{D}$ \\
\hline & L2 & D & D & $D$ & $D$ & $D$ & D & $D$ & D & $D$ & $D$ & D & $D$ \\
\hline & L3 & D & D & $D$ & $D$ & $D$ & D & $D$ & D & $D$ & $D$ & D & $\mathrm{D}$ \\
\hline & G1 & D & D & $D$ & $D$ & $D$ & D & $D$ & D & $D$ & $D$ & D & $D$ \\
\hline & G2 & D & D & D & D & D & D & $D$ & D & $D$ & D & $D$ & $D$ \\
\hline & G3 & D & D & $D$ & $\mathrm{D}$ & $D$ & D & $Q$ & D & $D$ & $D$ & $D$ & $D$ \\
\hline & A1 & 22,265 & D & $D$ & $\mathrm{D}$ & $D$ & D & $D$ & D & $D$ & $D$ & D & $\mathrm{D}$ \\
\hline & A2 & D & D & $D$ & $D$ & D & 162,87 & $\mathrm{D}$ & D & $D$ & $D$ & D & $\mathrm{D}$ \\
\hline & 11 & D & D & $D$ & $D$ & $D$ & D & $D$ & D & $D$ & $D$ & D & $D$ \\
\hline & 12 & D & D & D & $\mathrm{D}$ & D & D & $\mathrm{D}$ & D & D & D & D & D \\
\hline & B1 & D & D & D & $\mathrm{D}$ & D & D & $Q$ & D & $D$ & $D$ & $D$ & $D$ \\
\hline & B2 & D & D & $D$ & $D$ & $D$ & D & $D$ & D & $D$ & $D$ & $\mathrm{D}$ & $\mathrm{D}$ \\
\hline & B3 & D & D & D & $\mathrm{D}$ & D & D & $\mathrm{D}$ & D & D & D & $\mathrm{D}$ & D \\
\hline & B4 & D & D & $D$ & $D$ & D & D & $Q$ & D & $D$ & $D$ & D & $\mathrm{D}$ \\
\hline & B5 & D & D & $D$ & $D$ & $D$ & D & $D$ & D & $D$ & $\mathrm{D}$ & $D$ & $D$ \\
\hline & B6 & D & $D$ & $D$ & $\mathrm{D}$ & $D$ & D & $\mathrm{D}$ & D & $D$ & $D$ & $\mathrm{D}$ & $D$ \\
\hline & B7 & D & $Q$ & $D$ & $D$ & $D$ & D & $D$ & D & $D$ & $D$ & $D$ & $D$ \\
\hline & B8 & D & $D$ & $D$ & $D$ & $D$ & D & $D$ & D & $D$ & $\mathrm{D}$ & $D$ & $D$ \\
\hline
\end{tabular}




\subsection{Análise quimiométrica}

Para uma melhor interpretação dos resultados fez-se uso da ferramenta quimiométrica Análise de Agrupamentos Hierárquicos (HCA), agrupando as amostras por similariade entre elas.

Foram utilizadas as variáveis: depleção de oxigêio (OD - Cs), pH, potencial de oxirredução (ORP) e carbono orgânico dissolvido (COT).

\subsubsection{Campanha do inverno de 2014}

A Figura 17 mostra o resultado da HCA da campanha do inverno de 2014.

Figura 17 - HCA da campanha inverno 2014.

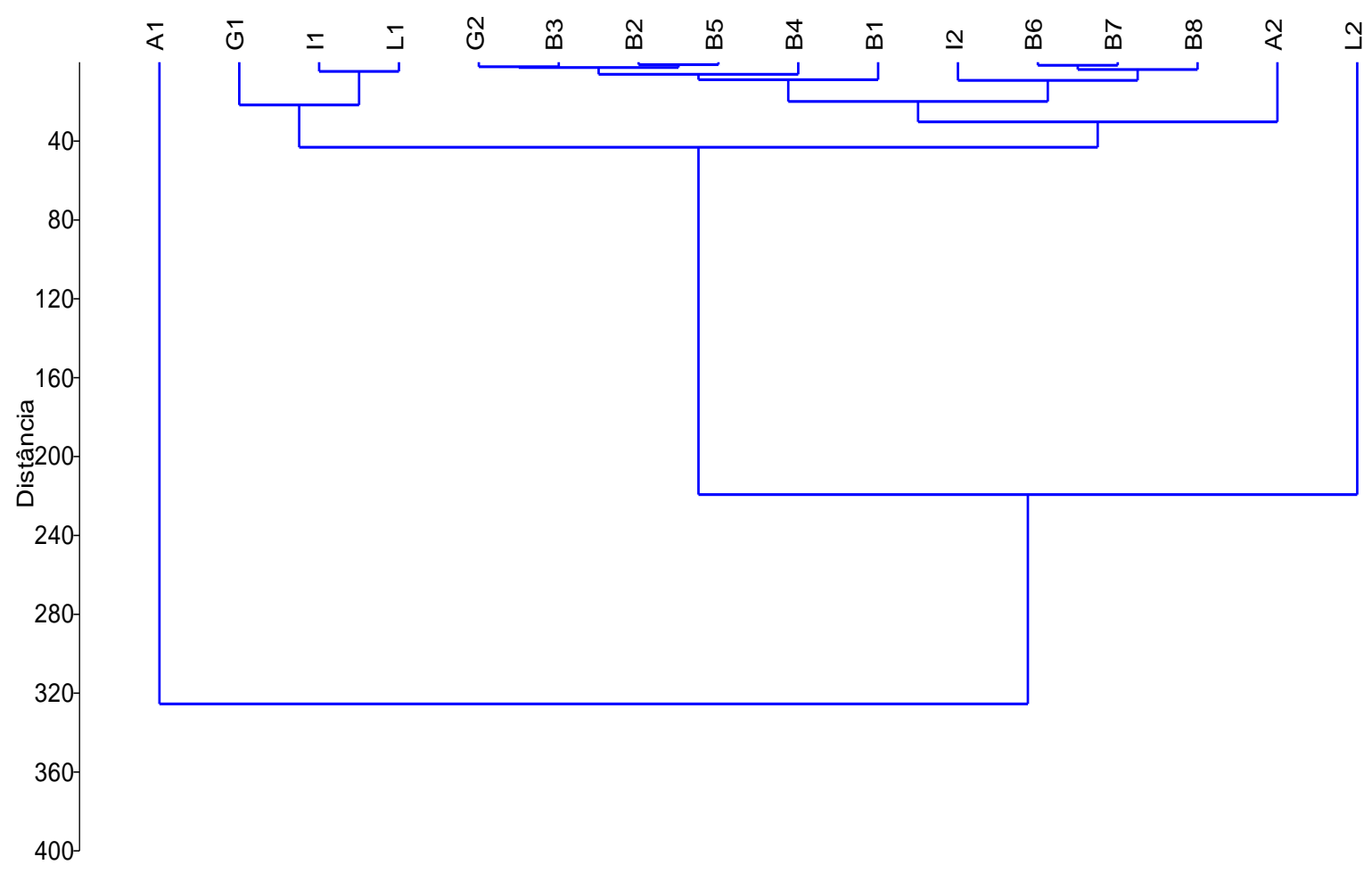

Pode-se notar que o ponto A1 é muito diferente dos demais e que o ponto L2 também se diferencia, porém em menor grau. Nota-se um agrupamento formado pelos pontos G1, I1 e L1 e outro por G2, A2, I2, B1, B2, B3, B4, B5, B6, B7 e B8. 
Analisando-se os dados brutos, verifica-se que o ponto A1 apresenta maior depleção de oxigênio e o menor potencial redox (ORP) de toda a campanha de amostragem de 2014 (-246,2 mV). O ponto L2 se diferencia dos demais por possuir o maior potencial redox da campanha de $2014(+283,8 \mathrm{mV})$. O ponto I1 se diferencia dos demais por apresentar a segunda maior depleção de oxigênio e o ponto A2 se diferencia dos demais por apresentar maior concentração de carbono orgânico dissolvido $\left(8,11 \mathrm{mg} \mathrm{L}^{-1}\right)$.

O cluster formado pelos pontos G1 e 11 apresentaram os menores valores de $\mathrm{pH}$ e os maiores valores de ORP, depois do ponto L2.

O agrupamento formado pelos pontos G2, 12, B1, B2, B3, B4, B5, B6, B7 e B8, não se destacam em nenhum parâmetro, nota-se que são pontos da baía e da foz dos rios.

Verificou-se a ocorrência de duas sulfonamidas - sulfametoxazol (A1 e I2) e sulfaquinoxalina (L2, G2 e B2) — e uma fluoroquinolona — norfloxacina (B5, B6, B7 e B8), na campanha de 2014.

O ponto A1 se destaca durante a análise dos resultados. Esse ponto é, de fato, muito diferente dos demais por apresentar a maior depleção de oxigênio e, consequentemente, um potencial redox negativo. Durante a coleta era forte o odor característico de sulfeto e havia muitos aguapés no rio, indicativos da eutrofização do corpo d'água.

Nota-se que os rios diferem entre si, tendo perfis de contaminação distintos. Porém, nenhum deles impacta, por si só, de maneira significativa a baía. Esta, por sua vez, apresenta perfis mais homogêneos apesar de, nos pontos B5, B6, B7 e B8 ter sido detectada a presença de norfloxacina, diferentemente dos outros pontos da baía. Observa-se também que os pontos nos quais foi detectada a presença de antimicrobianos são, de modo geral, pontos da baía e na foz dos rios, um indicativo de que a contaminação esteja ocorrendo, provavelmente, devido ao descarte de esgoto doméstico nos rios.

Dos três pontos na saída da baía, o B5 chama a atenção por ser o único no qual foi encontrada norfloxacina. Não foi observada no local nenhuma possível fonte 
deste fármaco. Logo, não se pôde chegar a uma conclusão sobre o que ocasionou a presença de norfloxacina no ponto B5.

\subsubsection{Campanha do verão de 2015}

A Figura 18 mostra o resultado da HCA na campanha do verão de 2014.

Figura 18 - HCA da campanha verão 2015.

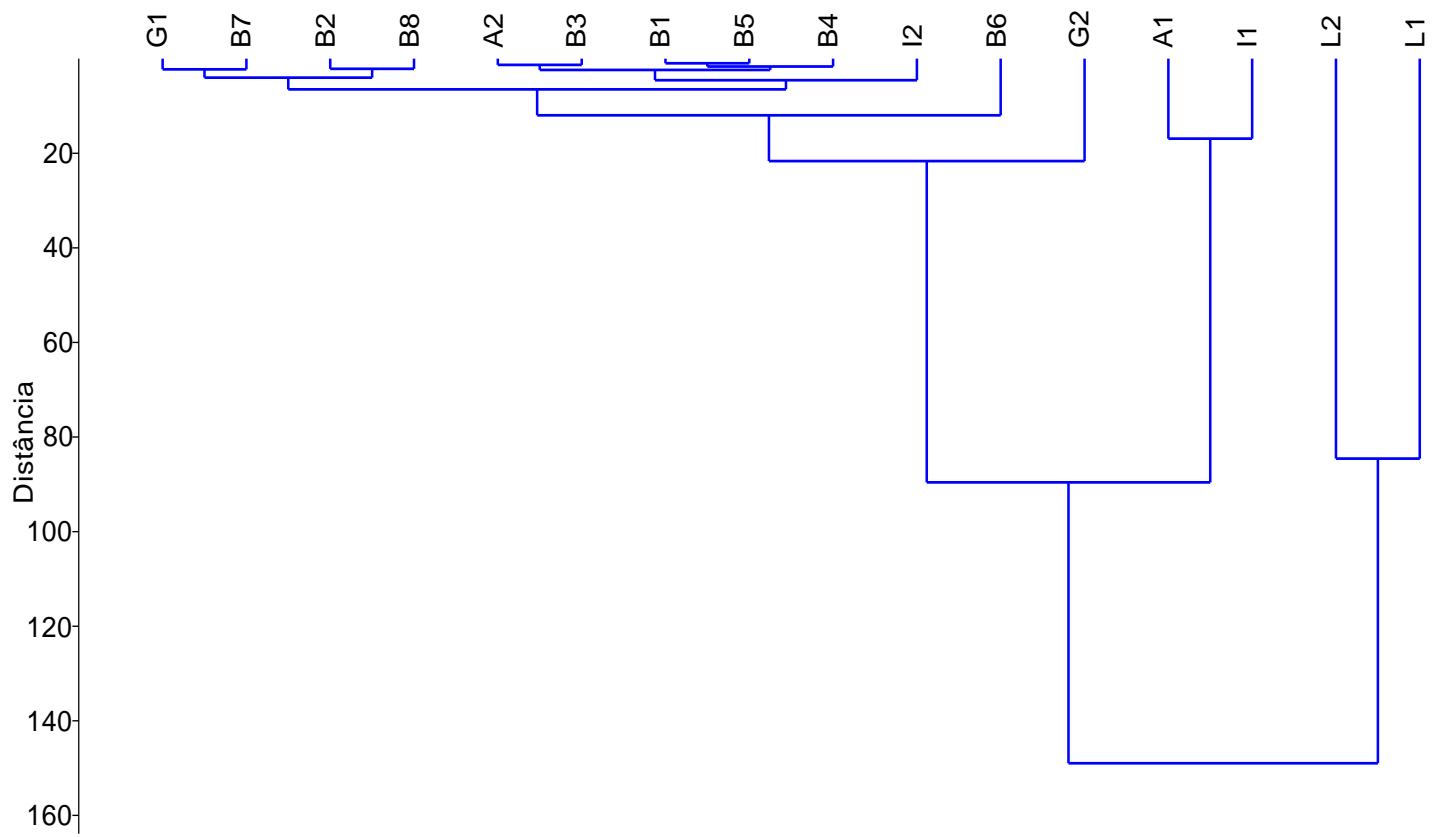

Analisando-se os dados brutos, verifica-se que os pontos L1 e L2 são diferentes dos demais, os pontos $A 1$ e 11 formam um agrupamento e os pontos $\mathrm{G} 1, \mathrm{G} 2, \mathrm{~A} 2$, 12, B1, B2, B3, B4, B5, B6, B7 e B8, outro.

Os pontos L1 e L2 diferem dos demais devido à variável ORP. Esses são os únicos pontos de amostragem que apresentaram potencial redox positivo na campanha de 2015 (+77,8 e +162,3 $\mathrm{mV}$, respectivamente).

Os pontos A1 e 11 diferem dos demais devido às variáveis depleção de oxigênio, COD e ORP, pois apresentaram os maiores valores de depleção de oxigênio $\left(-7,35\right.$ e -7,60 $\mathrm{mg} \mathrm{L}^{-1}$, respectivamente), os valores mais negativos de ORP $(-113,6 \mathrm{e}$ 
$-97,4 \mathrm{mV}$, respectivamente) e valores altos de $\operatorname{COD}\left(7,19\right.$ e $3,26 \mathrm{mg} \mathrm{L}^{-1}$, respectivamente) na campanha de 2015.

O agrupamento formado pelos pontos G1, G2, A2, I2, B1, B2, B3, B4, B5, B6, B7 e B8 não se destaca em nenhum parâmetro. Nota-se que são pontos da baía e da foz dos rios, com exceção do ponto G1.

Foram identificadas apenas sulfonamidas (sulfametoxazol, sulfatiazol, sulfacloropiridazina e sulfaquinoxalina) na campanha de 2015. Os pontos L1, G2, B1 e B4 são locais onde ocorreu a presença de sulfaquinoxalina (SQX), B7 a presença de sulfatiazol (STZ), A2 presença de sulfacloropiridiazina (SCP) e A1 a presença de sulfametoxazol (SMX).

Nota-se, novamente, que os rios diferem entre si tendo perfis de contaminação distintos. Porém, nenhum deles impacta, por si só, de maneira significativa a baía.

\subsubsection{Ambas campanhas de coleta}

A Figura 19 mostra o resultado da HCA de ambas as campanhas. 
Figura 19 - HCA de ambas as campanhas ( ${ }^{*}$ são pontos de amostragem do verão de 2015).

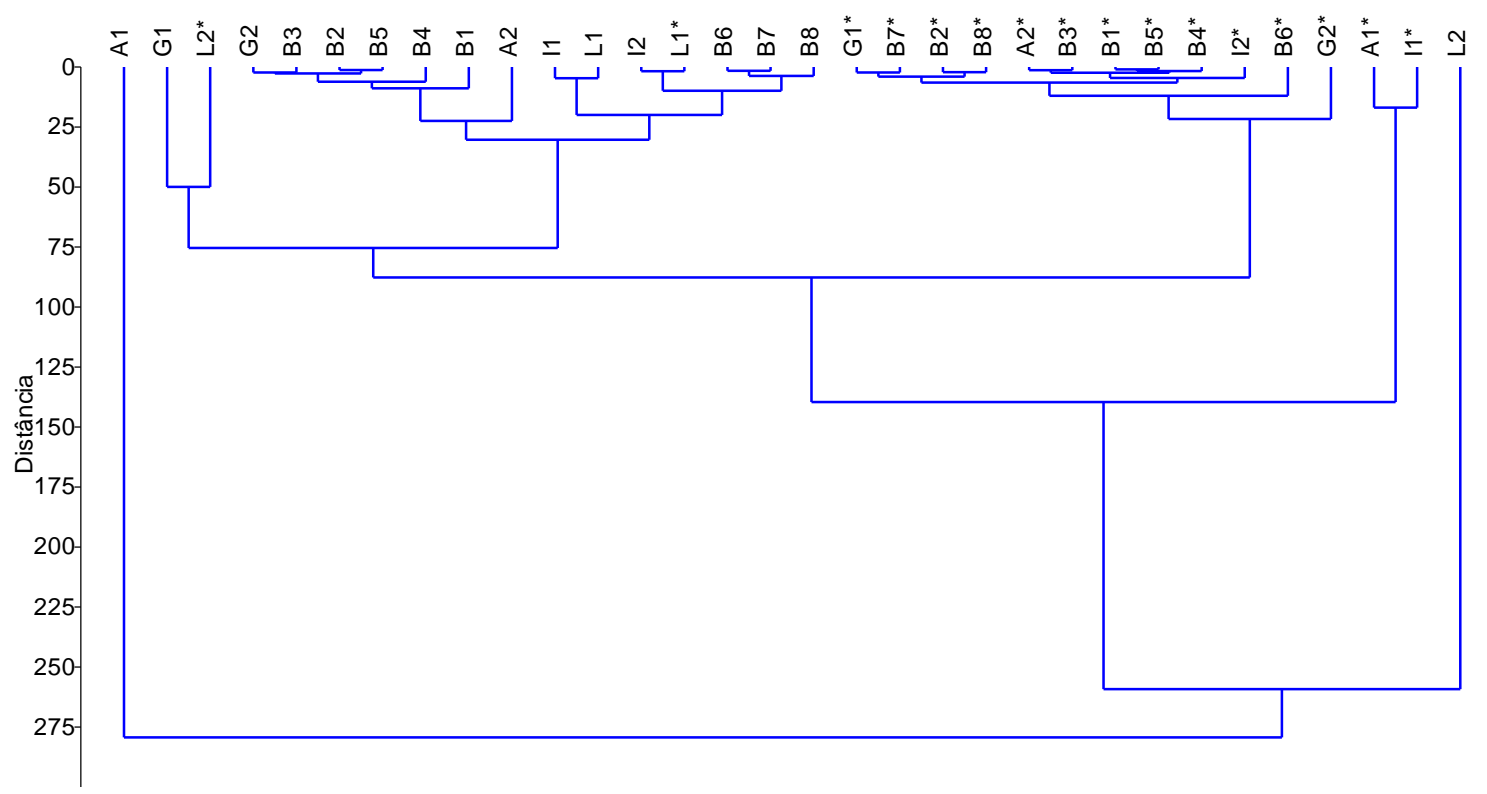

Pode-se notar, em geral, uma separação entre a campanha do inverno de 2014 e a campanha do verão de 2015.

Analisando-se os dados brutos percebe-se que a diferença mais marcante entre as duas campanhas de amostragem foi a mudança no ambiente redox das águas: no inverno, todos os locais de amostragem menos um apresentaram um potencial redox positivo (ambiente oxidante); no verão, a situação inverteu-se. Ou seja, todos os locais de amostragem menos um apresentaram um potencial redox negativo (ambiente redutor). Isso pode ser atribuído ao aumento expressivo da densidade demográfica neste período, causando uma maior contaminação por esgoto doméstico. Com relação ao pH, os locais de amostragem do inverno de 2014 estão levemente ácidos, enquanto no verão de 2015 estão levemente básicos, e com relação à depleção de oxigênio, de modo geral, no inverno de 2014 houve menor depleção do que no verão de 2015.

O ponto A1 se diferencia dos demais em ambas as campanhas, principalmente devido a uma baixa concentração de oxigênio dissolvido, potencial de oxirredução bem negativo, uma concentração de COD relativamente alta e a presença de SMX. A semelhança dos parâmetros observados sugere que o ponto A1 sofre contaminação constante, independentemente da época do ano. 
Os Rios Grande (G2) e Lagoa-Tavares (L2 em 2014 e L1 em 2015) apresentaram-se contaminados com SQX, nas duas campanhas de amostragem indicando, também, uma contaminação possivelmente constante ao longo do ano.

Observa-se a ocorrência de NOR nos pontos B5, B6, B7, B8 de 2014, ocorrência de SQX nos pontos B2, G2 e L2 em 2014 e L1, G2, B1, B4 em 2015.

Segundo dados do Instituto Nacional de Meteorologia - INMET, num período de 15 dias antes da coleta no inverno de 2014, a precipitação para a cidade de Parati-RJ, que é vizinha de Ubatuba-SP, foi de $41 \mathrm{~mm}$ e no verão de 2015, $95 \mathrm{~mm}$.

Considerando-se que a precipitação na cidade de Ubatuba também tenha dobrado no verão em relação ao inverno, esse aumento pode ter sido a causa da ausência de NOR na campanha do verão de 2015, já que esse fármaco teve o maior LOD dentre os detectados.

Um fator que pode ter contribuído para o fato de não terem sido detectadas outras fluoroquinolonas nas amostras coletadas é que elas sofrem fotólise em meio aquoso. A luz solar é capaz de promover a fotólise das fluoroquinolonas, mesmo na presença de outros compostos fotossensíveis, o que poderia fazer com que fossem rapidamente degradadas após o seu descarte (STURINI et al., 2012). 


\section{CONCLUSÃO}

Foi possível comprovar que os quatro rios pesquisados e a baía de Ubatuba encontram-se de alguma forma contaminados. Os dados obtidos sugerem que a contaminação mais frequente deva ser por esgoto doméstico, porém fazem-se necessárias análises adicionais, como fósforo total, nitrogênio total, DBO e DQO (estabelecidas pela resolução CONAMA 357/05) para se ter um maior grau de certeza.

Notadamente, o rio Acaraú encontrou-se bastante impactado. Em ambas as campanhas as análises feitas tiveram resultados próximos, mostrando uma contaminação recorrente deste corpo d'água. Segundo a CETESB, há uma estação de tratamento de esgoto (ETE) no rio Acaraú e todo o esgoto coletado no bairro de Praia Grande, após passar por uma ETE de responsabilidade da Associação dos Moradores de Praia Grande, é despejado no rio Acaraú. No entanto, a jusante da ETE, no trecho urbano, ele volta a receber vários despejos de esgoto doméstico.

O rio Grande estava impactado. Em ambas as campanhas de coleta houve a presença de SQX na foz e em todos os locais de amostragem houve depleção de oxigênio. O rio Lagoa-Tavares e o rio Indaiá também estavam impactados. Em todos os rios foram encontrados quimioterápicos antimicrobianos e, como era de se esperar, na baía que recebe suas águas também. É preocupante a presença de antibióticos nas amostras coletadas, pois pode estar sendo induzida resistência nas bactérias dos corpos d'água da região.

O uso da ferramenta quimiométrica Análise de Agrupamentos Hierárquicos (HCA), auxiliou a interpretação dos dados obtidos. Com ela foi possível visualizar grupos separados de acordo com a similaridade dos dados.

Observou-se uma variação espacial nos perfis de contaminação por quimioterápicos antimicrobianos nos corpos d'água pesquisados. Os rios Grande e LagoaTavares estiveram predominantemente contaminados com a SQX e os rios Acaraú e Indaiá com SMX. Já na baía, além dessas duas sulfas, detectou-se também a presença de NOR e STZ. Observou-se, ainda, que nenhum dos rios determinou os perfis de contaminação encontrados na baía. 
Uma variação temporal pode ser claramente observada na HCA, pois houve uma separação significativa das águas amostradas entre o inverno e o verão. As variáveis ORP, pH e depleção de oxigênio apresentaram diferenças significativas entre o inverno e o verão, o suficiente para diferenciar as campanhas. No verão de 2015 os locais de amostragem apresentaram-se com maior depleção de oxigênio e meio redutor, indicadores de uma possível contaminação por esgoto doméstico. Isso leva à conclusão de que o expressivo aumento demográfico no verão pressiona o ecossistema da região.

Por fim, pode-se dizer que é preocupante a situação da região da baía de Ubatuba, pois os rios que desembocam nela estão impactados pelo despejo de esgoto doméstico, fonte de quimioterápicos antimicrobianos nos corpos d’água. 


\section{PERSPECTIVAS FUTURAS}

Faz-se interessante a inclusão de outras variáveis aos dados brutos de modo a enriquecer a discussão dos dados e estas variáveis podem ser: nitrogênio total, fósforo total, DQO ou DBO e metais, isso em amostras de água e sedimentos. Considerando-se que cada metal analisado é uma variável, a somatória de todas resultaria em uma imensa tabela de dados e a utilização da ferramenta quimiométrica Análise por Componentes Principais (PCA) será uma ferramenta interessante para a interpretação dos dados.

O aumento do número de campanhas de coleta também seria interessante, pois assim pode-se perceber com maior clareza padrões temporais de contaminação nos corpos d'água.

Também deve ser considerada a inclusão de locais de amostragem próximos às nascentes dos rios, para que se tenham informações do corpo d'água antes deste percorrer a área urbana. Isso não foi feito neste trabalho devido ao difícil acesso a estes pontos. 


\section{REFERÊNCIAS}

ABRAHAM, W. R.; GOMES, M. A. J.; TAVARES, F. C. A. Occurrence and resistance of pathogenic bacteria along the Tietê River downstream of São Paulo in Brazil.

Clean - Soil, Air, Water, v. 35, n. 4, p. 339-347, 2007.

ADACHI, F.; YAMAMOTO, A.; TAKAKURA, K. I.; KAWAHARA, R. Occurrence of fluoroquinolones and fluoroquinolone-resistance genes in the aquatic environment. Science of the Total Environment, v. 444, p. 508-514, 2013.

AL-ODAINI, N. A.; ZAKARIA, M. P.; ZALI, M. A.; JUAHIR, H.; YAZIZ, M. I.; SURIF, S. Application of chemometrics in understanding the spatial distribution of human pharmaceuticals in surface water. Environmental Monitoring and Assessment, v. 184, n. 11, p. 6735-6748, 2012.

APPELBAUM, P. C.; HUNTER, P. A. The fluoroquinolone antibacterials: past, present and future perspectives. International Journal of Antimicrobial Agents, v. 16, n. 1 , p. $5-15,2000$.

BARAN, W.; ADAMEK, E.; ZIEMIAŃSKA, J.; SOBCZAK, A. Effects of the presence of sulfonamides in the environment and their influence on human health. Journal of Hazardous Materials, v. 196, p. 1-15, 2011.

BARRIONUEVO, W. R.; LANÇAS, F. M. Extração em fase sólida (SPE) e micro extração em fase sólida (SPME) de piretróides em água. Química Nova, v. 24, n. 2, p. 172-175, 2001.

BENSON, B. B.; KRAUSE, D. The concentration and isotopic fractionation of oxygen dissolved in freshwater and seawater in equilibrium with the atmosphere. Limnology and Oceanography, v. 29, n. 3, p. 620-632, 1984.

BERGAN, T. Pharmacokinetics of fluorinated quinolones. In: The quinolones. 2. ed. London: Academic Press, 1998. p. 119-154

BORG, M. A.; ZARB, P.; SCICLUNA, E. A.; RASSIAN, O.; GUR, D.; REDJEB, S. B.; ELNASSER, Z.; DAOUD, Z. Antibiotic consumption as a driver for resistance in Staphylococcus aureus and Escherichia coli within a developing region. American Journal of Infection Control, v. 38, n. 3, p. 212-216, 2010.

BURONE, L.; PIRES-VANIN, A. M. S. Foraminiferal assemblages in the Ubatuba Bay, south-eastern Brazilian Coast. Scientia Marina, v. 70, n. 2, p. 203-217, 2006.

BRASIL. Agência Nacional de Águas (ANA); Companhia de Tecnologia de Saneamento Ambiental (CETESB). Guia nacional de coleta e preservação de amostras: água, sedimento, comunidades aquáticas e efluentes líquidos. Brasília, 2011. $327 \mathrm{p}$. 
BRASIL. Agência Nacional de Águas (ANA). Portal da Qualidade das Águas. Indicadores de qualidade - Índice de Qualidade das Águas (IQA). Brasília, 2016. Disponível em: <http://portalpnqa.ana.gov.br/indicadores-indice-aguas.aspx>. Acesso em: 26 jul. 2016.

BRASIL. Agência Nacional de Vigilância Sanitária (ANVISA); Resolução - RE no 899: Guia para validação de métodos analíticos. Brasília, 2003. Disponível em: < http://www.anvisa.gov.br/legis/resol/2003/re/899_03 >. Acesso em: 18 mai. 2016

BRASIL. Ministério do Desenvolvimento Urbano e Meio Ambiente. CONAMA. Resolução n. ${ }^{\circ} 357$ de 17 de março de 2005. Disponível em: <http://www.mma.gov.br/port/ conama/res/res05/res35705.pdf>. Acesso em: 30 set. 2015.

BRASIL. Ministério do Desenvolvimento Urbano e Meio Ambiente. CONAMA. Resolução n. 9430 de 13 de maio de 2011. Disponível em: <http://www.mma.gov.br/port/ conama/legiabre.cfm?codlegi=646>. Acesso em: 28 jun. 2016.

BRASIL. Lei no 6938, de 31 de agosto de 1981. Dispõe sobre a Política Nacional do Meio Ambiente, seus fins e mecanismos de formulação e aplicação, e dá outras. Presidência da República. Disponível em: <http://www.planalto.gov.br/ccivil_03/ leis/L6938.htm>. Acesso em: 20 fev. 2016.

CENTERS FOR DISEASE CONTROL AND PREVENTION (CDC). Antibiotic resistance threats in the United States. 2014. , 2013. Disponível em: < http://www. cdc. gov/drugresistance/threat-report-2013> Acesso em: 20 fev. 2016.

CHEN, Y.; LEUNG, K. S. Y.; WONG, J. W. C.; SELVAM, A. Preliminary occurrence studies of antibiotic residues in Hong Kong and Pearl River Delta. Environmental Monitoring and Assessment, v. 185, n. 1, p. 745-754, 2013.

COMPANHIA DE TECNOLOGIA DE SANEAMENTO AMBIENTAL (CETESB). Qualidade das águas superficiais no Estado de São Paulo. São Paulo, 2011. 298 p. (Relatório técnico)

COMPANHIA DE TECNOLOGIA DE SANEAMENTO AMBIENTAL (CETESB). Qualidade das águas superficiais no Estado de São Paulo. São Paulo, 2015. 520 p. (Relatório técnico) DEBLONDE, T.; COSSU-LEGUILLE, C.; HARTEMANN, P. Emerging pollutants in wastewater: a review of the literature. International Journal of Hygiene and Environmental Health, v. 214, n. 6, p. 442-448, 2011.

ECDC, EFSA; EMEA, SCENIHR. Joint opinion on antimicrobial resistance (AMR) focused on zoonotic infections. European Food Safety Authority Journal (EFSA), v. 7, n. 11, p. 1372, 2009.

ENVIRONMENTAL PROTECTION AGENCY (EPA). Methods for Measuring the Acute Toxicity of Effluents and Receiving Waters to Freshwater and Marine Organisms. Washington, 2002. p. 32-34. Disponível em: < https://www3.epa.gov/ npdes/wettraining/module7/story_content/external_files/Acute\%20Tox\%205th\%20Edi tion.pdf > Acesso em: 20 ago. 2015 
GÖBEL, A.; McARDELL, C. S.; JOSS, A.; SIEGRIST, H.; GIGER W. Fate of sulfonamides, macrolides, and trimethoprim in different wastewater treatment technologies. Science of the Total Environment, v. 372, n. 2-3, p. 361-371, 2007.

HOOPER, D. C. Emerging mechanisms of fluoroquinolone resistance. Emerging Infectious Diseases, v. 7, n. 2, p. 337, 2001.

GRACIA-LOR, E.; SANCHO, J. V.; SERRANO, R.; HERNÁNDEZ, F. Occurrence and removal of pharmaceuticals in wastewater treatment plants at the Spanish Mediterranean area of Valencia. Chemosphere, v. 87, n. 5, p. 453-462, 2012.

GUERRA, P.; KIM, M.; SHAH, A.; ALAEE, M.; SMYTH, S. A. Occurrence and fate of antibiotic, analgesic/anti-inflammatory, and antifungal compounds in five wastewater treatment processes. Science of the Total Environment, v. 473, p. 235-243, 2014.

HALLER, M. Y.; MÜLlER, S. R.; McARDELL, C. S.; ALDER, A. C.; SUTER, M. J. F. Quantification of veterinary antibiotics (sulfonamides and trimethoprim) in animal manure by liquid chromatography-mass spectrometry. Journal of Chromatography A, v. 952, n. 1, p. 111-120, 2002.

HAMMER, Ø.; HARPER, D. A. T.; RYAN, P. D. PAST: Paleontological statistics software: package for education and data analysis. Palaeontologia Electronica, v. 4, n. 1, 2001.

INSTITUTO BRASILEIRO DE GEOGRAFIA E ESTATÍSTICA (IBGE). Censo 2010. 2010. Disponível em: <http://www.ibge.gov.br/cidadesat/link.php?codmun=355540>. Acesso em: 21 abr. 2015a.

INSTITUTO BRASILEIRO DE GEOGRAFIA E ESTATÍSTICA (IBGE). Censo 2010. 2010. Disponível em: <http://www.ibge.gov.br/home/estatistica/populacao/ censo2010/tabelas_pdf/Brasil_tab_1_10.pdf>. Acesso em: 21 abr. 2015b.

JARDIM, I. C. S. F.; Extração em fase sólida: fundamentos teóricos e novas estratégias para preparação de fases sólidas. Scientia Chromatographica, v. 2, n. 1, p. 13-25, 2010.

KAUSHAL, S. S.; LIKENS, G. E.; UTZ, R. M.; PACE, M. L.; GRESE, M.; YEPSEN, M. Increased river alkalinization in the Eastern US. Environmental Science \& Technology, v. 47, n. 18, p. 10302-10311, 2013.

KHETAN, S. K.; COLLINS, T. J. Human pharmaceuticals in the aquatic environment: A challenge to green chemistry. Chemical Reviews, v. 107, n. 6, p. 2319-2364, 2007.

KÖHN, H. F.; HUBERT, L. J. Hierarchical cluster analysis. Wiley StatsRef: Statistics Reference Online, 2006.

LANÇAS, F. M.; Extração em fase sólida (SPE). In: Métodos cromatográficos de análise. São Carlos: RiMa, 2004. 93 p. 
LIN, J. S.; PAN, H. Y.; LIU, S. M.; LAI, H. T. Effects of light and microbial activity on the degradation of two fluoroquinolone antibiotics in pond water and sedient. Journal of Environmental Science and Health Part B, v. 45, n. 5, p. 456-465, 2010.

LOCATELLI, M. A. F.; SODRÉ, F. F.; JARDIM, W. F. Determination of antibiotics in Brazilian surface waters using liquid chromatography-electrospray tandem mass spectrometry. Archives of Environmental Contamination and Toxicology, v. 60, n. 3, p. 385-393, 2011.

MAHIQUES, M. M.; TESSLER, M. G.; FURTADO, V. V. Characterization of energy gradient in enclosed bays of Ubatuba region, South-Eastern Brazil. Estuarine, Coastal and Shelf Science, v. 47, n. 4, p. 431-446, 1998.

MARTINEZ, J. L. Environmental pollution by antibiotics and by antibiotic resistance determinants. Environmental Pollution, v. 157, n. 11, p. 2893-2902, 2009.

MARTINS, A. F.; VASCONCELOS, T. G.; HENRIQUES, D. M.; FRANK, C. S.; KONIG, A.; KUMMERE, K. Concentration of ciprofloxacin in Brazilian hospital effluent and preliminary risk assessment: A case study. Clean - Soil, Air, Water, v. 36, n. 3, p. 264-269, 2008.

MEYER, T.; BENNIE, D.; ROSA, F.; PALABRICA, V.; REKAS, G.;

SCHACHTSCHNEIDER, J.; MARVIN, C. Dispersal of contaminants from municipal discharges as evidenced from sedimentary records in a Great Lakes coastal wetland, Cootes Paradise, Ontario. Journal of Great Lakes Research, v. 34, n. 3, p. 544558, 2008.

MUNARON, D.; TAPIE, N.; BUDZINSKI, H.; ANDRAL, B.; GONZALEZ, J. Pharmaceuticals, alkylphenols and pesticides in Mediterranean coastal waters: Results from a pilot survey using passive samplers. Estuarine, Coastal and Shelf Science, v. 114, n. SI, p. 82-92, 2012.

MUNIZ, P.; VENTURINI, N.; PIRES-VANIN, A. M.; TOMMASI, L. R.; BORJA, A. Testing the applicability of a Marine Biotic Index (AMBI) to assessing the ecological quality of soft-bottom benthic communities, in the South America Atlantic region. Marine Pollution Bulletin, v. 50, n. 6, p. 624-637, 2005.

NA, G.; GU, J.; GE, L.; ZHANG, P.; WANG, Z.; LIU, C.; ZHANG, L. Detection of 36 antibiotics in coastal waters using high performance liquid chromatography-tandem mass spectrometry. Chinese Journal of Oceanology and Limnology, v. 29, n. 5, p. 1093-1102, 2011.

PANDA, S. K.; PATRA, A. K.; KAR, R. N. Monitoring of multiple drug-resistant pathogens in a selected stretch of Bay of Bengal, India. Environmental Monitoring and Assessment, v. 184, n. 1, p. 193-200, 2012.

QIANG, Z.; ADAMS, C. Potentiometric determination of acid dissociation constants (pK a) for human and veterinary antibiotics. Water Research, v. 38, n. 12, p. 28742890, 2004. 
QUEIROZ, S. C. N; COLLINS, C. H.; JARDIM, I. C. S. F. Métodos de extração e/ou concentração de compostos encontrados em fluidos biológicos para posterior determinação cromatográfica. Química Nova, v. 24, n. 1, p. 68-76, 2001.

RAHMAN, M.; HUYS, G.; KUHN, I.; RAHMAN, M.; MOLLBY, R. Prevalence and transmission of antimicrobial resistance among Aeromonas populations from a duckweed aquaculture based hospital sewage water recycling system in Bangladesh. Antonie van Leeuwenhoek International Journal of General and Molecular Microbiology, v. 96, n. 3, p. 313-321, 2009.

SABESP. Apresenta informações virtuais do serviço prestado na cidade de Ubatuba. 2016a. Disponível em: <http://site.sabesp.com.br/site/interna/ Municipio.aspx?secaold=18\&id=623>. Acesso em: 01 maio 2016.

SABESP. Apresenta informações virtuais do serviço prestado na cidade de Ubatuba.. 2016b. Disponível em:<http://site.sabesp.com.br/ site/imprensa/releasesDetalhes.aspx?secaold=193\&id=6597>. Acesso em: 01 maio 2016.

SARMAH, A. K.; MEYER, M. T.; BOXALL, A. B. A. A global perspective on the use, sales, exposure pathways, occurrence, fate and effects of veterinary antibiotics (VAs) in the environment. Chemosphere, v. 65, n. 5, p. 725-759, 2006.

SECRETARIA DA JUSTIÇA E DA DEFESA DA CIDADANIA (SJDC). Inaugurados fóruns de Ubatuba e llhabela. 2006. Disponível em: <http://www.justica.sp.gov.br/ novo_site/Noticia.asp?Noticia=2543>. Acesso em: 27 jun. 2012.

SENA, M. M.; POPPI, R. J.; FRIGHETTO, R. T. S.; VARALINI, P. J. Avaliação do uso de métodos quimiométricos em análise de solos. Quimica nova, v. 23, n. 4, p. 547-556, 1999.

SHOPPING DO LABORATÓRIO. Apresenta informações virtuais do produto para coletas. 2016. Disponível em: < https://shoppingdolaboratorio.com.br/p-2023812GARRAFA\%20VAN\%20DORN\%20PVC\%202\%20L\%20(AFK\%2034)> Acesso em: 17 maio 2016.

SIGMA-ALDRICH. Supel-Select HLB SPE for Pharmaceutical Analysis. 2016. Disponível em: <http://www.sigmaaldrich.com/technical-documents/articles/reporterus/supel-select-hlb-spe.html> Acesso em: 17 maio 2016.

SINGH, S. P.; AZUA, A.; CHAUDHARY, A.; KHAN, S.; WILLETT, K. L.; GUARDINALI, P. R. Occurrence and distribution of steroids, hormones and selected pharmaceuticals in South Florida coastal environments. Ecotoxicology, v. 19, n. 2, p. 338- 350, 2010.

SIMEONOV, V.; STEFANOV, S.; TSAKOVSKI, S. Environmetrical treatment of water quality survey data from Yantra River, Bulgaria. Mikrochimica Acta, v. 134, n. 1-2, p. 15-21, 2000.

SMITH, R.; COAST, J.. The true cost of antimicrobial resistance. British Medical Journal (BMJ), v. 346, n. f1493, 2013. 
STURINI, M.; SPELTINI, A.; MARASCHI, F.; PRETALI, L.; PROFUMO, A.; FASANI, E.; ALBINI , A.; MIGLIAVACCA, R.; NUCLEO, E. Photodegradation of fluoroquinolones in surface water and antimicrobial activity of the photoproducts. Water Research, v. 46, n. 17, p. 5575-5582, 2012.

THOMAS, K. V.; HILTON, M. J. The occurrence of selected human pharmaceutical compounds in UK estuaries. Marine Pollution Bulletin, v. 49, n. 5-6, p. 436-444, 2004.

WATERS. Apresenta informações virtuais dos produtos de extração de amostras Oasis ${ }^{\circledR}$. 2016. Disponível em: <http://www.waters.com/webassets/cms/category/ media/detail_page_images/oasisspe_detail_1.gif> Acesso em: 17 mai. 2016.

WETZSTEIN, H. G.; SCHMEER, N.; KARL, W. Degradation of the fluoroquinolone enrofloxacin by the brown rot fungus Gloeophyllum striatum: Identification of metabolites. Applied and Environmental Microbiology, v. 63, n. 11, p. 4272-4281, 1997.

WILLE, K.; NOPPE, H.; VERHEYDEN, K.; BUSSCHE, J. V.; WULF, E. D.; CAETER, P. V.; JANSSEN, C. R.; DRABANDER, H. F. D.; VANHAECKE, L. Validation and application of an LC-MS/MS method for the simultaneous quantification of 13 pharmaceuticals in seawater. Analytical and Bioanalytical Chemistry, v. 397, n. 5, p. 1797-1808, 2010.

WOLFSON, J. S.; HOOPER, D. C. The fluoroquinolones: Structures, mechanisms of action and resistance, and spectra of activity in vitro. Antimicrobial Agents and Chemotherapy, v. 28, n. 4, p. 581-586, 1985.

XU, W.; ZHANG, G.; ZOU, S.; LI, X.; LIU, Y. Determination of selected antibiotics in the Victoria Harbour and the Pearl River, South China using high-performance liquid chromatography-electrospray ionization tandem mass spectrometry. Environment Pollution, v. 145, n. 3, p. 672-679, 2007.

YAN, C.; YANG, Y.; ZHOU, J.; LIU, M.; NIE, M.; SHI, H.; GU, L. Antibiotics in the surface water of the Yangtze Estuary: Occurrence, distribution and risk assessment. Environmental Pollution, v. 175, p. 22-29, 2013.

YANG, Y.; FU, J.; PENG, H.; HOU, L.; LIU, M.; ZHOU, J. L. Occurrence and phase distribution of selected pharmaceuticals in the Yangtze Estuary and its coastal zone. Journal of Hazardous Materials, v. 190, n. 1-3, p. 588-596, 2011.

ZHANG, R.; ZHANG, G.; ZHENG, Q.; TANG, J.; CHEN, Y.; XU, W.; ZOU, Y.; CHEN. $X$. Occurrence and risks of antibiotics in the Laizhou Bay, China: Impacts of river discharge. Ecotoxicology and Environmental Safety, v. 80, p. 208-215, 2012.

ZOU, S.; XU, W.; ZHANG, R.; TANG, J.; CHEN, Y.; ZHANG, G. Occurrence and distribution of antibiotics in costal water of the Bohai Bay, China: Impacts of river discharge and aquaculture activities. Environmental Pollution, v. 159, n. 10, p. 2913-2929, 2011. 